\title{
Finding the Most Efficient Way to Remove Residual Copper from Steel Scrap
}

\author{
KATRIN E. DAEHN, ANDRÉ CABRERA SERRENHO, and JULIAN ALLWOOD
}

The supply of end-of-life steel scrap is growing, but residual copper reduces its value. Once copper attaches during hammer shredding, no commercial process beyond hand-picking exists to extract it, yet high-value flat products require less than 0.1 wt pet copper to avoid metallurgical problems. Various techniques for copper separation have been explored in laboratory trials, but as yet no attempt has been made to provide an integrated assessment of all options. Therefore, for the first time, a framework is proposed to define the full range of separation routes and evaluate their potential to remove copper, while estimating their energy and material input requirements. The thermodynamic, kinetic, and technological constraints of the various techniques are analyzed to show that copper could be removed to below $0.1 \mathrm{wt}$ pet with relatively low energy and material consumption. Higher-density shredding allows for greater physical separation, but requires proper incentivization. Vacuum distillation could be viable with a reactor that minimizes radiation heat losses. High-temperature solid scrap pre-treatments would be less energy intensive than melt treatments, but their efficacy with typical shredded scrap is yet unconfirmed. The framework developed here can be applied to other impurity-base metal systems to coordinate process innovation as the scrap supply expands.

https://doi.org/10.1007/s11663-019-01537-9

(C) The Author(s) 2019

\section{INTRODUCTION}

THE amount of steel discarded yearly will triple from the present day to 2050, as predicted by Pauliuk et al. ${ }^{[1]}$ using a global stock-saturation model. Milford et al. ${ }^{[2]}$ have shown that much more steel must be produced from scrap to meet emissions targets, and utilizing this growing resource is a sound economic strategy. ${ }^{[3]}$ However, the presence of contaminating elements restricts the applications in which end-of-life scrap can replace primary steel. Copper is the most pervasive contaminant for steel scrap, present as wiring in vehicles, appliances and equipment, and alloyed with steel in engine blocks and powder metallurgy products. During hammer shredding, copper wiring entangles with the fragmented steel scrap. Subsequent magnetic separation is not completely effective, and steel-encased motors often remain with the steel scrap. Copper is not currently extracted from the steel melt, ${ }^{[4]}$ and it can lead to metallurgical problems during downstream

KATRIN E. DAEHN, ANDRÉ CABRERA SERRENHO, and JULIAN ALLWOOD are with the Department of Engineering, University of Cambridge, Trumpington Street, CB2 1PZ, Cambridge, UK. Contact e-mail: jma42@cam.ac.uk

Manuscript submitted September 7, 2018.

Article published online February 27, 2019. thermo-mechanical processing, such as resistance to hot rolling and surface hot shortness, as reviewed by Rod et al. ${ }^{[5]}$ Shredded end-of-life scrap typically has 0.4 wt pct copper, which can be tolerated in reinforcing bar, but many flat steel products require less than $0.1 \mathrm{wt}$ pct copper. ${ }^{[6]}$ As a result, today's primary and secondary steelmakers generally serve different markets, but in the future this strategy will become impractical. Analysis of the global steel cycle estimates that the amount of copper in scrap will exceed the amount which can be tolerated across all products by 2050 unless methods for improved control are introduced. ${ }^{[7]}$

Copper contamination could be managed by interventions at various points along the steel scrap supply chain. Figure 1 provides a representation of the stakeholders involved in the steel cycle, considering the steps each is responsible for and the incentives each has to control copper. The makers of cars, appliances, and equipment could use less copper (by challenging the trend of incorporating more electronic features, ${ }^{[8]}$ or using aluminum wiring instead $\left.{ }^{[9]}\right)$, or modify designs for easy disassembly at end-of-life (such as using detachable wiring harnesse ${ }^{[10]}$ ). However, product re-designs must be motivated by consumer support or regulation. A compromise in performance or price for enhanced recyclability may be unacceptable. Additionally, steel 


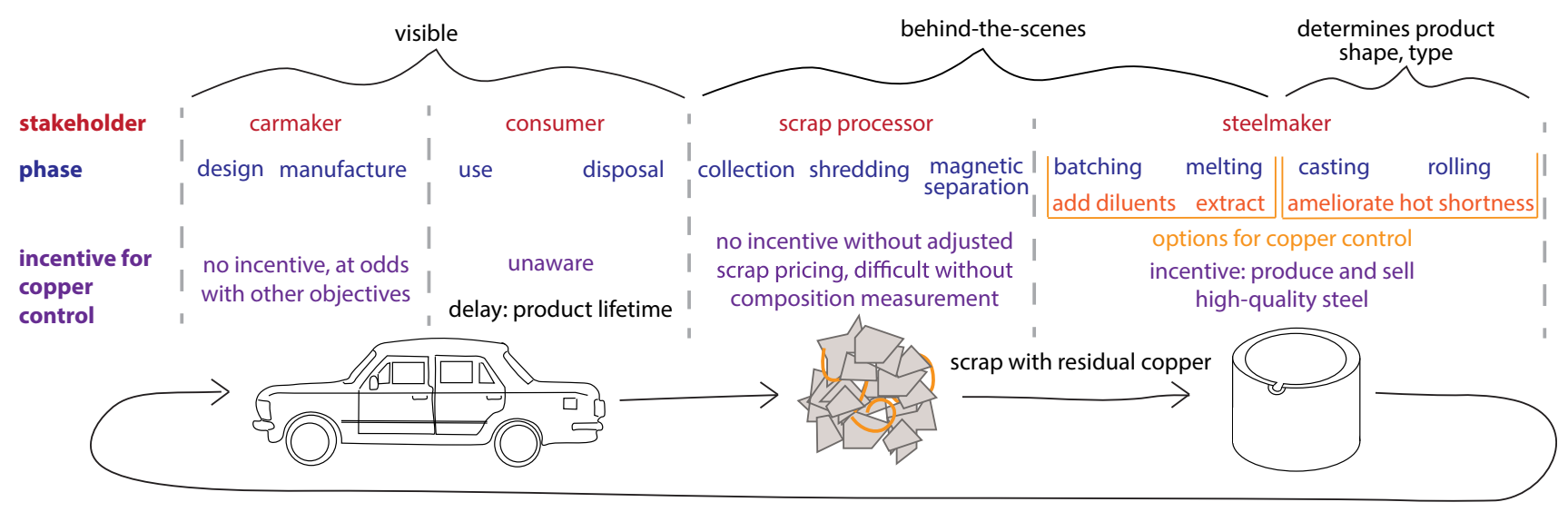

Fig. 1-Stakeholders along the steel supply chain, the steps each is responsible for, and the current incentives for improved copper control.

products have long lifetimes, so improvements at the product design stage would have a delay of at least 10 years before affecting the recycling process.

The scrap processor collects, dismantles, and shreds steel products for recycling. Copper removal at this point would be highly energy-efficient. Separation is always more efficient before mixing - as the concentration of a component in a mixture decreases, the work to extract it increases. ${ }^{[11]}$ However, manual disassembly to remove copper before shredding is labor intensive and cost prohibitive in many regions. ${ }^{[12]}$

Currently, the incentive to reduce the copper concentration of steel is to produce and sell high-value steel products. Thus, the steelmaker benefits from purer scrap. The steelmaker could incentivize the scrap processor to minimize contamination, but scrap is difficult to grade and price by copper concentration. The composition of scrap is known if it originates from production or manufacturing, but the copper concentration of end-of-life scrap cannot be measured until it is mixed with other raw materials and melted (unless neutron activation analysis technology is used, which is operating in at least 20 plants $^{[13]}$ ). Although mutual agreements between the scrap merchant and steelmaker can be arranged, in scrap classifications, ${ }^{[14,15]}$ shredded scrap is nominally the same whether it contains 0.4 or 0.1 wt pet copper.

Therefore, steelmakers must manage copper-contaminated scrap for the foreseeable future. There are ways to tolerate copper and avoid hot shortness. Sampson et al. ${ }^{[16]}$ show that silicon additions alter the formation of liquid copper at the surface. Casting and rolling processes that employ adjusted atmospheres or heating/cooling profiles are also promising, ${ }^{[17]}$ but the universal applicability of these techniques is uncertain. Such approaches prescribe the product composition and shape-for example, the thickness of steel produced by direct strip casting is limited to 10 to $15 \mathrm{~mm} \cdot{ }^{[18]}$ Alternatively, extraction would be an effective, behind-the-scenes solution to enable the high-quality recycling of steel. The scope of this paper is therefore on processes the steelmaker could employ to extract residual copper.
Copper removal processes are explored in a wide collection of literature. These studies are dispersed in time (1950-present) and geography (centered in the U.S., Japan, Germany, Russia). Reviews of the area, such as those by Savov et al., ${ }^{19]}$ Jimbo et al., ${ }^{[20]}$ and Noro et al..$^{[21]}$ as well as reports of multi-year collaborative projects ${ }^{[22,23]}$ summarize possible removal techniques, focusing mainly on vacuum distillation and sulfide slagging. Interest in the subject is now dated, as the rapid growth in primary steel production in the last 20 years ${ }^{[24]}$ has reduced the urgency to address the problem of copper contamination. Revisiting this collection of literature, it is unclear whether experimental research explored all options and in what direction to take future work. In reviewing the challenges of future metal recycling, Reck et al. ${ }^{[25]}$ warn that tramp element removal would be costly and energy intensive. Beyond this comment by Reck et al., ${ }^{[25]}$ no estimates of the energy requirements of tramp element extraction exist. A comprehensive and quantified comparison of the various techniques has not been attempted. This paper therefore aims to evaluate the feasibility of copper removal from a physical basis by defining the feasible separation routes, characterizing each with thermodynamic and kinetic descriptions and estimating the energy and material inputs required when the process is integrated into the recycling circuit.

\section{CONSTRUCTING AND APPLYING A NEW FRAMEWORK TO ASSESS COPPER-STEEL SEPARATION PROCESSES}

Existing literature examines the thermodynamic constraints of copper removal from steel. These analyses and their limitations are discussed in Section II-A. A new methodology is needed to evaluate a wider range of options and enrich current understanding, so this paper proposes a framework, introduced at the end of Section II-A. Section II-B describes the application of this framework to the copper-steel system. 


\section{A. Current Methods and the Need for a New Framework}

There are two forms of thermodynamic analysis: process-independent and process-dependent. Process-independent assessments provide a theoretical measure of the work required to separate an impurity. Available thermodynamic information on iron-based $\mathrm{Fe}-\mathrm{Cu}$ melts was compiled by Zaitsev et al., ${ }^{[26]}$ who found the activity coefficient of copper in an infinitely dilute solution is 8.8 at $1600{ }^{\circ} \mathrm{C}$. Carbon additions only increase the activity coefficient of copper. Wang et al. ${ }^{[27]}$ compile values from researchers, reporting between 16 and 31 in carbon-saturated melts at $1600{ }^{\circ} \mathrm{C}$. An activity coefficient greater than 1 denotes a repulsive interaction between the components in solution. Thus, considering only this interaction, copper should be relatively easy to remove. An energy requirement of roughly $1 \mathrm{kWh} /$ tonne steel to reduce copper concentration in iron from 0.4 to $0.1 \mathrm{wt}$ pct copper follows from the Gibbs free energy difference reported by Zaitsev et al..$^{[26]}$ at $1550{ }^{\circ} \mathrm{C}$.

Process-independent thermodynamic analysis gives the minimum amount of energy required for separation theoretically, but this analysis alone provides a limited evaluation. As Rousseau ${ }^{[28]}$ explains, if only the first law of thermodynamics governed separation, the thermodynamic energy requirement would correlate directly with the fuel required. However, the second law distorts this relationship. The energy flows, both quantity and quality, through a system must be considered. Thus, the separation process must be defined, and Gutowski ${ }^{[29]}$ explains that the more detailed the process model, the more reflective the energy requirement estimates will be to true practice.

Therefore, process-dependent thermodynamic analysis, which analyzes the extent to which an impurity is removed in a specific process, can be useful for understanding separation in practice. For steelmaking today, the main technique used to control impurities is the application of an oxidizing slag. Castro et al. ${ }^{[30]}$ used the oxygen partial pressure and activity of the impurity in the melt to calculate its equilibrium distribution to an oxidizing slag. Later, Nakajima et al. ${ }^{[31]}$ expanded on this calculation to incorporate the effect of temperature, composition of the slag, and vapor pressure. Both assessments conclude that copper cannot be removed from the melt using this technique, because iron oxidizes preferentially to copper.

The scope of the current process-dependent analyses is limited, as they evaluate the process used in industry today, but neglect the wider range of processes that could be developed in the future. Current industrial practice evolved due to historic and economic factors. Steel refining began with the primary route, where oxidation effectively controls impurities present in ores and reductants: mainly carbon, phosphorus, and silicon. The waste stream introduces new elements not found in the primary route (such as copper), and techniques to control these elements could exist, but have not yet been commercially developed.
In summary, thermodynamics shows copper could be removed in theory, but not by the current practice of oxidation. The assessments do not evaluate the options existing between theory and industrial practice, but the laboratory investigations mentioned in the introduction show this space is worth investigating. Each experimental study evaluates copper removal under specific conditions, but a structure to provide an overall understanding of feasibility and to give direction to these investigations is lacking. The proposed framework therefore links the two forms of analysis, shown in Figure 2(a). Theoretical separation principles serve as the basis for evaluating potential scaled-up processes. Once processes are defined, meaningful estimations of effectiveness and energy requirements can be made.

\section{B. Applying the Framework to Copper in Steel}

To understand the overall feasibility of removing copper from steel, various means must be identified and then assessed. The proposed framework does this in four steps: first, find the possible separation routes, and then for each route define the rate of copper reduction, define a potential process, and estimate the energy and material consumption. Applying these steps to the copper-steel system is described in Sections II-B-1 to II-B-4.

\section{Step 1: finding the possible separation routes}

A wide range of equilibrium and transport phenomena can be used in separation. In this step, in order to organize the different phenomena while covering the full range of possible options, "separation routes" for a general impurity metal-base metal system are defined, and the applicability of each route to the copper-steel system is evaluated.

For a general impurity-base metal system, there are two main starting states: the impurity can be heterogeneously mixed with solid scrap, or in the liquid phase as a homogeneous mixture which is formed upon melting. From these beginning states, a separation route can be defined for all possible separate phases to which the impurity can be moved and collected. Here, distinct routes are defined by the end state of the impurity. This scheme is shown in Figure 3 for solid scrap, and Figure 4 for the melt.

In all routes, separation is driven by a difference in properties between the impurity and base metal through the use of a separating agent, as described by King. ${ }^{[32]}$ King proposes a classification scheme to categorize these property differences and separating agents. Accordingly, here the separations are categorized into three distinct types, which are indicated by the coloring of the separating agent in Figures 3 and 4 . The first is energy-based physical separations, in which energy is applied to exploit a difference in physical properties, such that the impurity changes phase. There are also mass-based physical separations, where material is 
Assessments: current and proposed

Process-independent thermodynamic characterization of impurity- base metal interaction

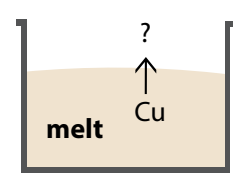

Little energy is required to separate copper from liquid steel, but the removal mechanism is not defined.

Framework

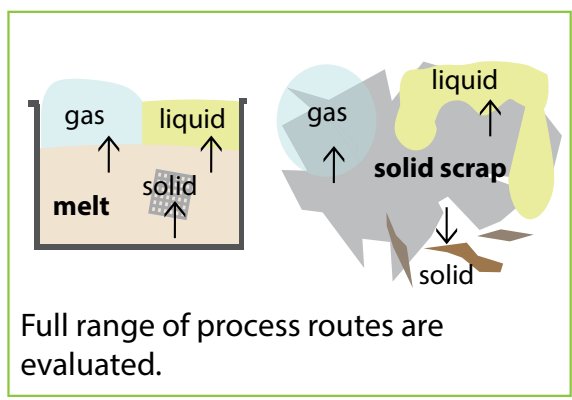

Process-depedent thermodynamic behavior of impurity in current commercial refining

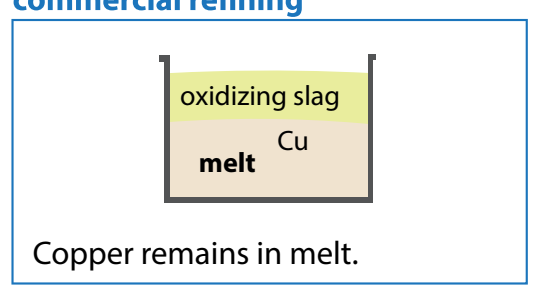

(a)
Framework steps

Theory 1. Find possible separation routes. Identify the differences in physical and chemical properties that can be used to collect $\mathrm{Cu}$ in a separate phase.

For each identified route:

2. Describe the rate of copper reduction.

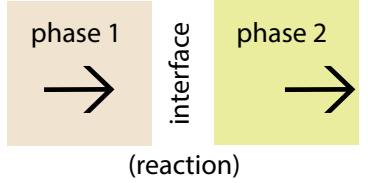

Quantify the decrease in copper concentration over time, and the process window in which the description applies.

\section{Define the potential process.}

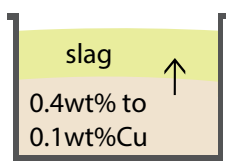

Match the required process conditions to an industrial reactor and calculate the time required to reduce from 0.4 to $0.1 \mathrm{wt} \% \mathrm{Cu}$.

\section{Estimate energy and material consumption.}

Estimate the specific energy and material consumption of the process, when integrated into conventional recycling.

Fig. 2-The current assessments and the proposed framework for evaluating the feasibility of removing copper from steel are shown in the left column $(a)$. Steps of the framework are shown in the right-hand column, $(b)$. The framework evaluates possible separations, from theoretical principles to the energy and material inputs required in practice, thus filling the gap between the process-independent and process-dependent assessments.

added to the system to act as a collection site or induce a phase change. Lastly, in chemical separations, a reactant is applied to preferentially react with the impurity, thus exploiting chemical property differences. In all cases, the magnitude of the exploited property difference is an $a$ priori indication of feasibility. To apply this general scheme to the copper-steel system, the relevant property differences are identified and discussed, and are presented with references for all routes in Figures 5 (solid scrap) and 6 (melt).

Energy-based separations for copper and steel exploit physical property differences in the solid state or during vaporization, melting, and solidification. As solid scrap, copper can be separated from steel due to differences in magnetic permeability or density, and such processes are in standard operation, but depend on the liberation achieved during shredding. Copper has a higher vapor pressure such that it can be distilled from a steel melt, and it has a lower melting point so that it can be melted while steel remains solid. Copper partitions to the liquid phase during solidification of iron, but to the solid phase during the solidification of carbon-saturated iron. In both cases, the partition coefficient is close to 1 , indicating limited partitioning.

Physical mass-based separations include applying a solvent or filter to extract copper. Relevant solvents can be identified with phase diagrams, which reveal differences in miscibility. Iron is immiscible with lead and silver, while copper is miscible. A miscibility gap exists between iron and aluminum as well, but only at lower temperatures, so aluminum is a viable solvent when applied to solid scrap. Filtration has been cursorily investigated, with Savov et al. ${ }^{[19]}$ reporting that a ceramic filter or particles of $\mathrm{Al}_{2} \mathrm{O}_{3}-\mathrm{ZrO}_{2}$ selectively adsorb copper from an iron melt. 


\begin{tabular}{|c|c|c|c|c|}
\hline beginning state & route & separating agent & end state & property difference \\
\hline \multirow[b]{5}{*}{ solid scrap } & \multirow{2}{*}{$\begin{array}{l}\text { reactive gas } \\
\text { evaporation }\end{array}$} & \multirow[b]{2}{*}{ gas } & \multirow{2}{*}{$\begin{array}{l}\text { gas } \\
\text {-impurity-compound }\end{array}$} & \multirow{2}{*}{ — affinity and volatility } \\
\hline & & & & \\
\hline & preferential & \multirow[b]{2}{*}{ energy } & liquid & \\
\hline & melting & & \multirow{2}{*}{$\begin{array}{l}\text { liquid } \\
\text { - melted } \\
\text { - impurity in solution }\end{array}$} & \\
\hline & $\begin{array}{l}\text { solvent } \\
\text { extraction }\end{array}$ & \multirow{2}{*}{ solvent } & & _ melting \\
\hline \multirow{3}{*}{ separation type } & matte & & \multirow{3}{*}{$\begin{array}{l}\text { impurity-compound } \\
\text { in matte } \\
\text { dissolved in leachant }\end{array}$} & \\
\hline & extraction & matte & & — affinity \\
\hline & leaching & leachant & & _ dissolution behavior \\
\hline \multirow{2}{*}{$\begin{array}{c}\text { physical } \\
\text { energy-based }\end{array}$} & \multirow{2}{*}{$\begin{array}{l}\text { magnetic } \\
\text { separation }\end{array}$} & \multirow[b]{2}{*}{ energy } & solid & \multirow[b]{2}{*}{ _ magnetic permeability } \\
\hline & & & \multirow{2}{*}{$\begin{array}{l}\text { impurity } \\
\text { impurity }\end{array}$} & \\
\hline $\begin{array}{c}\text { physical } \\
\text { mass-based }\end{array}$ & \begin{tabular}{|l|} 
density \\
separation
\end{tabular} & energy & & - density \\
\hline chemical & embrittlement & -atmosphere & $\begin{array}{l}\text { embrittled } \\
\text { compound }\end{array}$ & $\begin{array}{l}\text { fracture toughness/ } \\
\text { adhesion }\end{array}$ \\
\hline
\end{tabular}

Fig. 3- General routes to remove an impurity from solid scrap, showing the separating agent applied in each route and the property difference exploited.

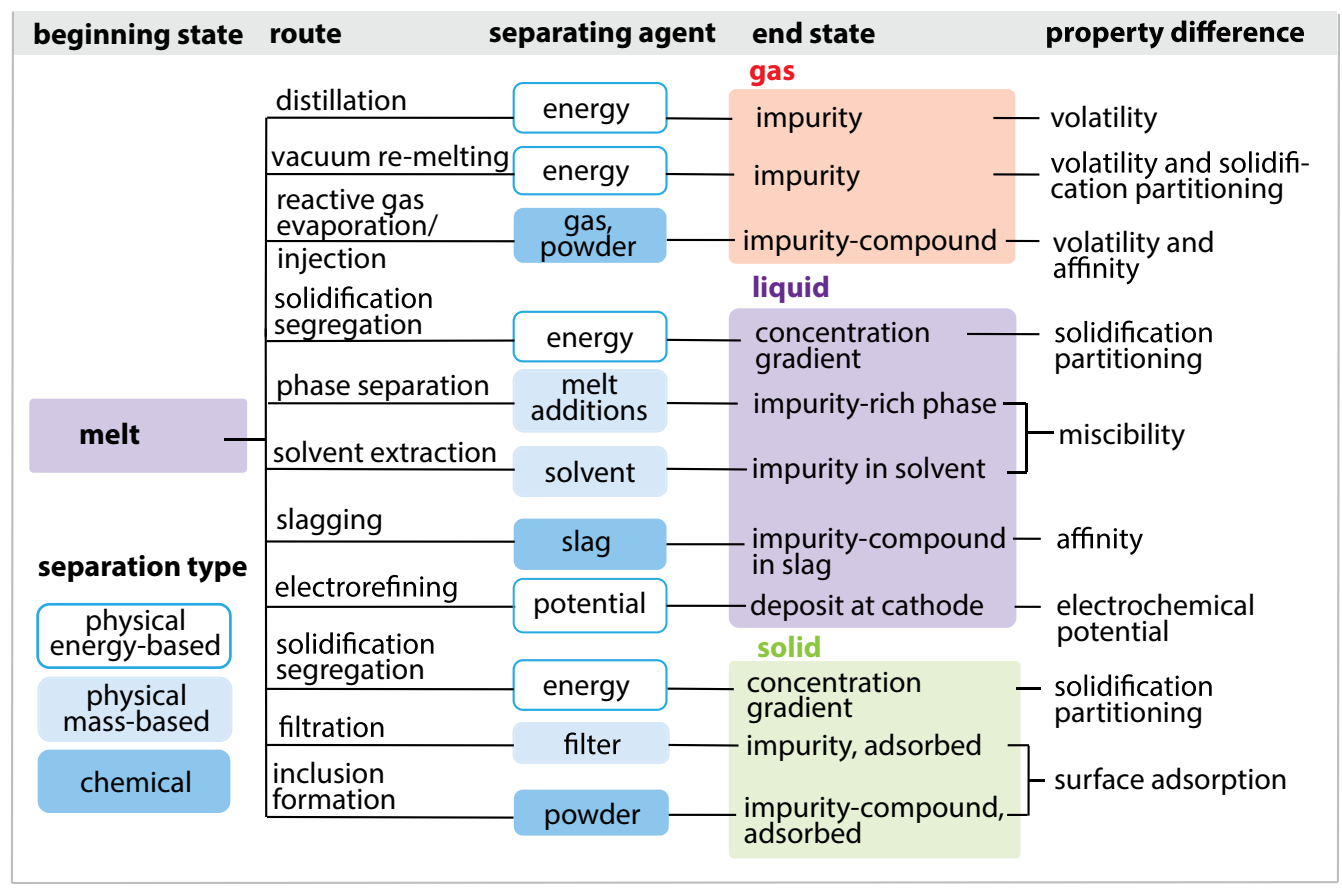

Fig. 4-General routes to remove an impurity from the melt, showing the separating agent applied in each route and the property difference exploited.

In chemical separations, copper undergoes a chemical reaction preferentially to steel. Sulfur is the only element that will react preferentially with copper, and this is the principle behind sulfide-based slags and mattes. However, researchers have identified viable chemical separations beyond sulfidation. Process windows exist to separate copper from steel through chlorination, oxidation, and leaching. Chlorination is viable at certain ratios of oxygen and chlorine: copper chloridizes, while iron oxidizes to prevent its chlorination. ${ }^{[33]}$ To separate copper through oxidation, the lower fracture toughness of copper oxide is exploited. Brittle copper oxide can be collected by tumbling mixed scrap in an oxidizing atmosphere around $650{ }^{\circ} \mathrm{C} \cdot{ }^{[34]}$ In these conditions, iron forms adherent $\mathrm{Fe}_{2} \mathrm{O}_{3}$ at the surface, so iron loss is minimal. In leaching, copper dissolves in an electrolyte while iron remains inert or passivates. Ammonia-based leachants have the highest selectivity and have received the most attention. ${ }^{[35]}$ Other chemical separations have been attempted experimentally, but the principles have not been confirmed. Ammonia-based gases were sprayed onto the steel melt to accelerate the evaporation of 


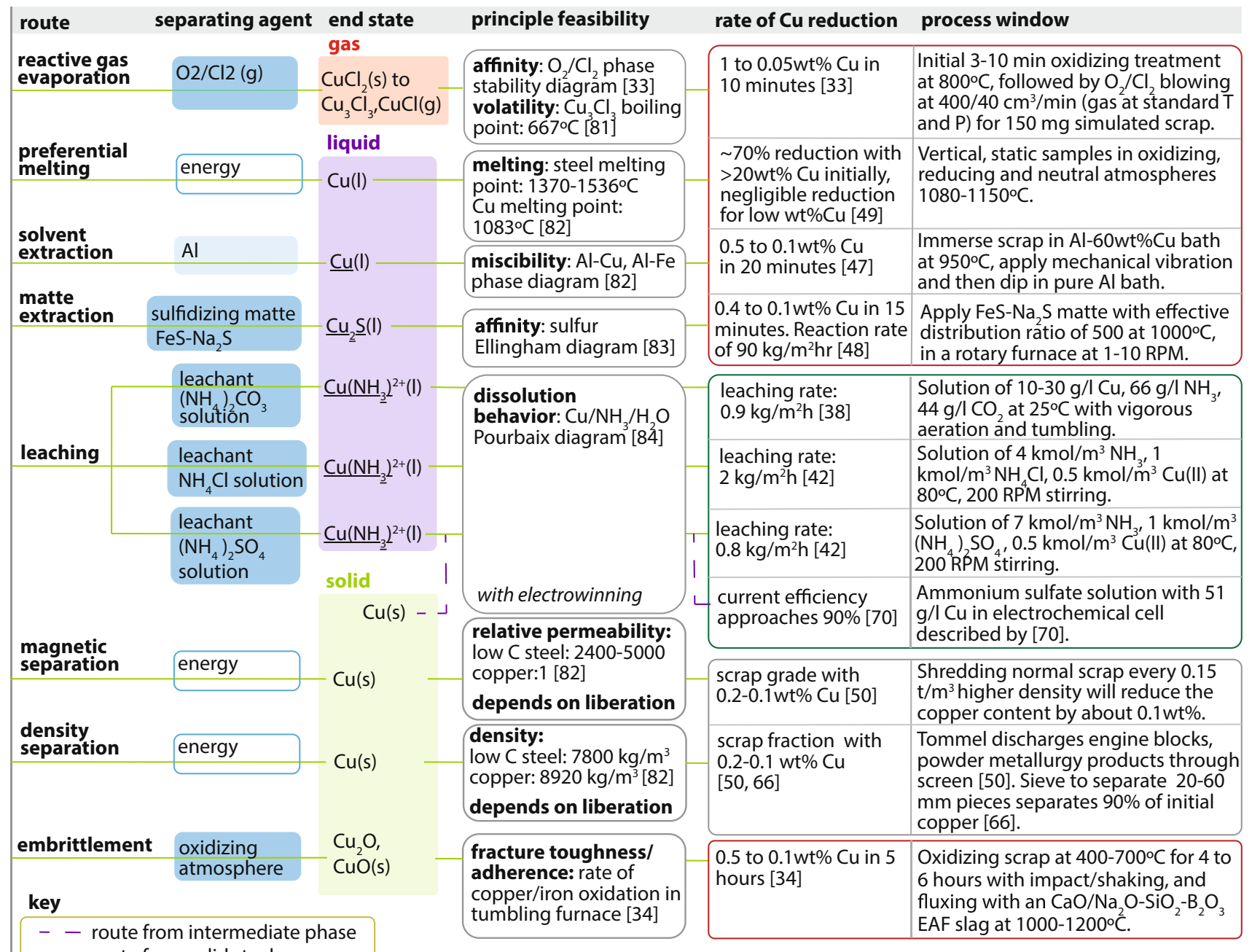

Fig. 5-Copper separation routes from solid scrap with the associated measure of principle feasibility, rate of copper reduction, and the process window in which it applies (summary of framework steps 1 to 3). The boxes surrounding the rate of copper reduction and process window information correspond with the process type: physical (gray), high temperature (red), and leaching (green) (Color figure online).

copper. Researchers hypothesize that volatile $\mathrm{CuH}(\mathrm{g})^{[36]}$ or $\mathrm{Cu}\left(\mathrm{N}_{3}\right)_{2}(\mathrm{~g})^{[37]}$ forms. To form copper-containing inclusions, Oden et al. ${ }^{[38]}$ injected a range of complex alkali and alkaline earth compounds into the melt (chosen because of the stability of the associated copper-containing compounds), but the experiments were unsuccessful.

The above classification identifies the relevant physical property differences that can be exploited in energy-based separations, and the relevant solvents, filters, and reactants that can be applied in mass-based separations. The next steps evaluate the requirements and limitations of applying the identified principles in practice. This evaluation is dependent on previous experimental results, so all experimental works found in the literature were catalogued according to the distinct routes. This catalogue can be found in the electronic supplementary material. Information directly used for analysis is cited in the manuscript.

\section{Step 2: describing the rate of copper reduction}

This step seeks to quantify the rate of reaction - the decrease in copper concentration over time-for the various routes shown in Figures 5 and 6. In all of these routes, copper collects in a separate end phase. The reaction happens at the interface between the beginning phase and end phase. The total reaction proceeds by three main steps: transport of the reactants to the interface, the reaction at the interface, and transport of products away from the interface. Rate laws are experimentally determined and depend on process variables, such as temperature, chamber pressure, and the extent of stirring. These variables determine which of the three kinetic steps is rate-determining (or the rate could be mixed-controlled by one or more of the steps). The catalogue of experimental results was used to identify the rate equation, and the process window in which this equation applies, for the routes in Figures 5 and 6. The kinetics 


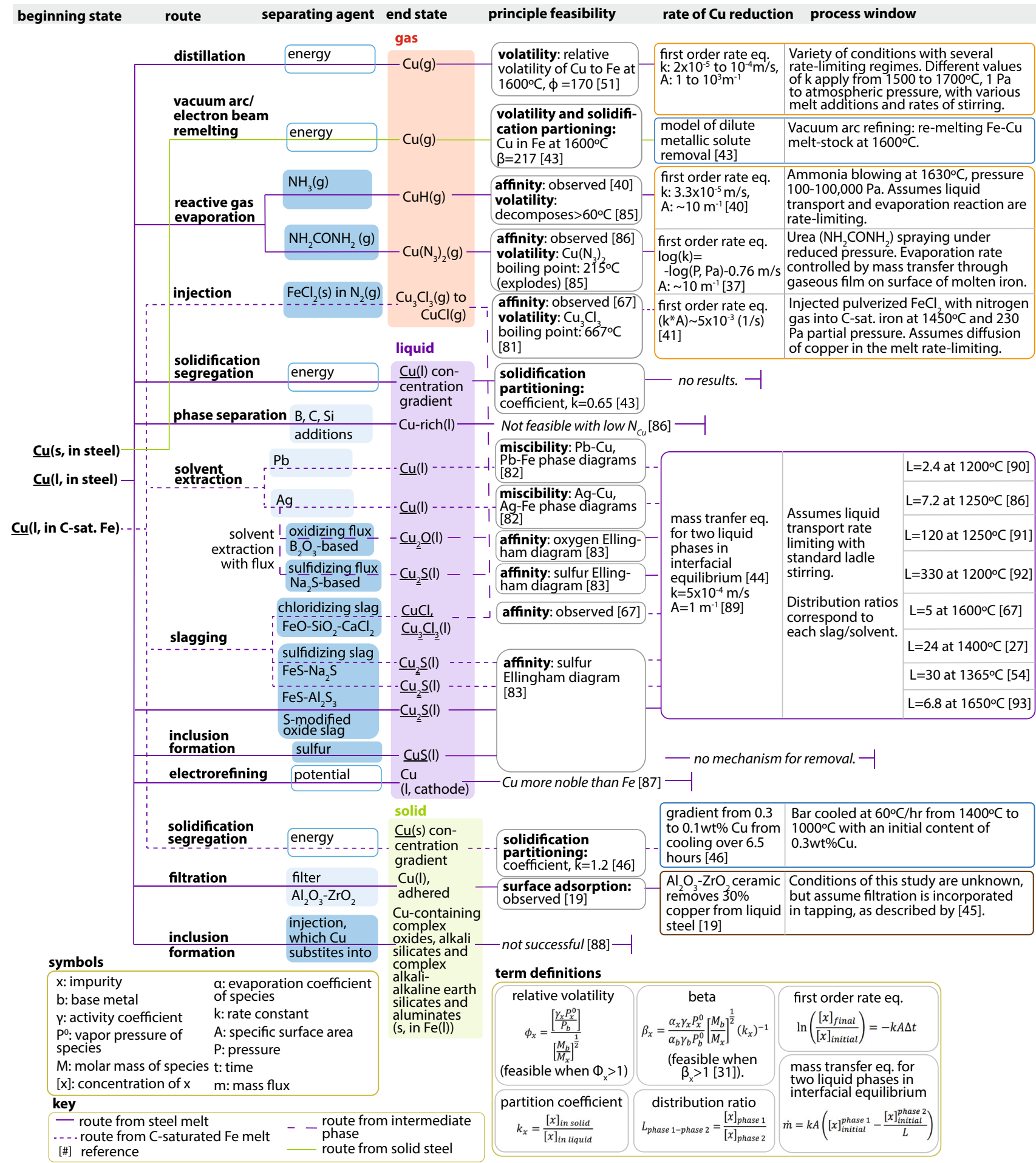

Fig. 6-Copper separation routes from the steel melt, with the associated measure of principle feasibility, rate of copper reduction, and the process window in which it applies (summary of framework steps 1 to 3). The boxes surrounding the rate of copper reduction and process window information correspond with the process type: vacuum treatments (orange), slagging ladle treatments (purple), filtration (brown), and solidification segregation (blue) (Color figure online).

of many routes have not been fully evaluated, so in these cases, other experimental results are applied to estimate the rate at which copper is removed.
Rate equations have been determined for the reduction of copper concentration in distillation, reactive gas evaporation, leaching, and vacuum arc refining. Distilling pure copper from an iron-based melt is governed by 
a first-order rate equation. A range of different process conditions can be employed, and there are several different rate-limiting regimes. ${ }^{[39]}$ Existing experimental work provides over 60 data points for the rate of copper concentration reduction in these regimes, which is presented in the electronic supplementary material. First-order rate equations have been determined for the gaseous removal of copper when ammonia, ${ }^{[40]}$ urea, ${ }^{[37]}$ or a chloridizing powder injection ${ }^{[41]}$ is applied to an iron-based melt, but these equations apply only within the process window of the respective studies. The dissolution rate of copper in ammonia-based solutions has been studied extensively. Oden et al. ${ }^{[38]}$ investigate ammonium carbonate solutions, while Konishi et al. ${ }^{[42]}$ investigate the leaching rate of ammonium chloride and sulfate solutions while varying temperature and stirring rate. The maximum leaching rates, and the associated process windows revealed by these studies are used here. The kinetics of solute removal during vacuum arc refining was investigated by Andreini and Foster ${ }^{[43]}$ and their proposed model is used here.

The remaining routes have not previously been characterized by a rate equation, so other information is used to estimate the rate of copper concentration reduction. To describe the removal of copper from the melt by a solvent or slag, the general rate equation for impurity removal during slag refining in steelmaking is used, ${ }^{[4]}$ with experimentally determined distribution ratios for copper with the specific solvent and slag compositions. This assumes that transfer of copper through the melt phase is rate-limiting. There is no information available on the kinetics of copper removal by filtration, but Ghosh ${ }^{[45]}$ estimates the decrease in the flow rate if a ceramic filter were employed in steel tapping. With this set-up, the removal ratio reported by Savov et al. ${ }^{[19]}$ for an $\mathrm{Al}_{2} \mathrm{O}_{3}-\mathrm{ZrO}_{2}$ ceramic is assumed. For unidirectional segregation, Nakamoto et al. ${ }^{[46]}$ describes the copper concentration gradient achieved in carbon-saturated iron with a specific cooling profile, and these results are used. For solid scrap treatments at elevated temperatures, namely applying a chloridizing gas, ${ }^{[33]}$ aluminum solvent ${ }^{[47]}$ or sulfidizing matte ${ }^{[48]}$ as well as preferential melting ${ }^{[49]}$ and oxygen embrittlement ${ }^{[34]}$ experimental results provide the removal ratio of copper following a given treatment. These experiments show the chemical reaction is rapid, but the proportion of copper removed is limited by transport of reactants to, and products away from, the reaction site, which is dependent on the physical shape of the scrap. The physical presence of copper in typical shredded scrap, and the limitations this imposes for these techniques, has not been characterized, as experiments used simulated scrap. The rate of copper removal during magnetic separation and density separation similarly depends on prior shredding and fragmentation. However, copper removal during industrial magnetic separation as a function of shredded scrap density is reported by Newell. ${ }^{[50]}$ Newell ${ }^{[50]}$ also describes how a copper-rich fraction of scrap could be isolated using a trommel system. Overall, the description for the rate of copper removal determined for each route and the conditions for which it applies are shown in Figures 5 and 6 .

\section{Step 3: defining the potential processes}

This new framework aims to evaluate the feasibility of the various means to separate copper from steel, and this must account for the process requirements in practice. In the previous step, the rates of copper removal within certain process windows were evaluated. In practice, the required process conditions are delivered by industrial reactors. Therefore in this step, an industrial reactor, which could deliver the temperature, rates of stirring/agitation, and contact with reactants as stipulated in the last column of Figures 5 and 6, was identified for each route. For distillation, a range of process conditions have been investigated so several potential processes are defined, including standard vacuum degassing. Scalable processes have been proposed in the academic literature or patents for the chloridizing gas treatment, ${ }^{[33]}$ oxygen embrittlement, ${ }^{[34]}$ leaching with ammonium carbonate, ${ }^{[38]}$ vacuum distillation, ${ }^{[51-53]}$ and slagging with $\mathrm{FeS}-\mathrm{Al}_{2} \mathrm{~S}_{3} .{ }^{[54]}$ Improved shredding and physical separation have already been demonstrated at scale. ${ }^{[50]}$

The proposed reactor and process conditions for each route are shown in Figures 7 (solid scrap treatments) and 8 (melt treatments). The routes fall into the following types of processes: solid scrap physical separation, high-temperature solid scrap treatments, leaching, vacuum treatments, slagging ladle treatments, filtration, and solidification segregation. With an appropriate reactor and process conditions stipulated, treatment time can be estimated. The time to achieve $0.1 \mathrm{wt}$ pct copper from an initial copper concentration of $0.4 \mathrm{wt}$ pct was determined for all cases, using the relationships from Step 2. Some processes cannot achieve $0.1 \mathrm{wt}$ pct copper, so the time to reach the greatest reduction in copper concentration possible is calculated. The estimated treatment time for each process is shown in Figures 7 and 8.

\section{Step 4: estimating specific energy and material consumption}

This last step evaluates the specific energy and material consumption of the processes defined in Step 3 . It is assumed that each process would be integrated into the conventional steel recycling route, as shown in Figure 9. The energy - heat and mechanical — as well as material inputs required directly by the treatment, per tonne of steel treated, are estimated. Secondary effects of the treatment on the composition of steel, and additional energy and materials consumed as a consequence, are identified and added as well. A full break down of the sources of specific energy and material consumption for each process can be found in the electronic supplementary material.

The heat required for each process is estimated by calculating a heat balance. The assumptions behind the heat balance for each process type (melt treatments, high-temperature solid scrap treatments, leaching and solidification segregation) are explained here. For melt 


\begin{tabular}{|c|c|c|c|c|c|c|c|c|}
\hline process route & reactant & reactor & $\mathbf{T}\left({ }^{\circ} \mathrm{C}\right)$ & $\begin{array}{l}\text { time } \\
(\min )\end{array}$ & $\begin{array}{l}{\left[\mathrm{Cu}_{\mathrm{F}}\right]} \\
(\mathbf{w t} \%)\end{array}$ & \multicolumn{2}{|c|}{$\begin{array}{l}\text { sources of energy consumption } \\
\text { (per tonne steel) }\end{array}$} & \multirow{2}{*}{$\begin{array}{l}\text { secondary } \\
\text { effects } \\
\text { improved yield, } \\
\text { cleanliness in } \\
\text { EAF }\end{array}$} \\
\hline $\begin{array}{l}\text { improved } \\
\text { shredding, } \\
\text { magnetic } \\
\text { separation }\end{array}$ & & $\begin{array}{l}\text { hammer shredder at lower } \\
\text { process rate, or shredded in } \\
\text { several passes, for } 1.2-1.5 \mathrm{t} / \mathrm{m}^{3} \\
\text { density. }\end{array}$ & 25 & varies & $0.2-0.1$ & $\begin{array}{l}\text { electricity for more } \\
\text { intensive shredding or } \\
\text { iterations ( } 2-3 \text { passes) }\end{array}$ & $20-40 \mathrm{kWh} / \mathrm{t}[65]$ & \\
\hline $\begin{array}{l}\text { separate } \\
\text { copper-rich } \\
\text { fraction with } \\
\text { sieve/trommel }\end{array}$ & & $\begin{array}{l}\text { trommel system described by } \\
\text { [50]. }\end{array}$ & 25 & varies & $0.2-0.1$ & $\begin{array}{l}\text { shaking/vibration } \\
\text { electricity for trommel } \\
\text { system }\end{array}$ & $\begin{array}{l}0.5 \mathrm{kWh} / \mathrm{t} \\
0.5 \mathrm{kWh} / \mathrm{t}[94]\end{array}$ & $\begin{array}{l}\text { divert/further } \\
\text { process } \\
\text { copper-rich } \\
\text { fraction. } \\
\end{array}$ \\
\hline \multirow[t]{2}{*}{$\begin{array}{l}\text { reactive gas } \\
\text { evaporation }\end{array}$} & \multirow[t]{2}{*}{$\mathrm{O}_{2} / \mathrm{Cl}_{2}$} & \multirow[t]{2}{*}{$\begin{array}{l}\text { chlorination process } \\
\text { described by [33]. }\end{array}$} & \multirow[t]{2}{*}{800} & \multirow[t]{2}{*}{10} & \multirow[t]{2}{*}{0.1} & $\begin{array}{l}\text { total process energy } \\
\text { consumption }\end{array}$ & $\begin{array}{l}27 \mathrm{kWh} / \mathrm{t} \text { estimated } \\
\text { by [33], assuming } \\
\text { scrap at } 800^{\circ} \mathrm{C}\end{array}$ & \multirow[t]{5}{*}{$\begin{array}{l}\text { Fe oxidation, } \\
\text { external } \mathrm{Zn}, \text {,Sn } \\
\text { also chloridize. }\end{array}$} \\
\hline & & & & & & transition into EAF & $10-20 \mathrm{kWh} / \mathrm{t}$ & \\
\hline \multirow[t]{3}{*}{$\begin{array}{l}\text { preferential } \\
\text { melting }\end{array}$} & & \multirow{3}{*}{$\begin{array}{l}\text { continuous conveyor scrap } \\
\text { heating in tunnel furnace (as } \\
\text { demonstrated by Consteel: } \\
\text { [58]) with vibration applied } \\
\text { above } 1083^{\circ} \mathrm{C} \text {. }\end{array}$} & \multirow[t]{3}{*}{1100} & \multirow[t]{3}{*}{$5-10$} & \multirow[t]{3}{*}{$0.4-0.35$} & $\begin{array}{l}\text { powering furnace during } \\
\text { treatment }\end{array}$ & $3-5 \mathrm{kWh} / \mathrm{t}$ & \\
\hline & & & & & & shaking/vibration & $0.5 \mathrm{kWh} / \mathrm{t}$ & \\
\hline & & & & & & transition into EAF & $10-20 \mathrm{kWh} / \mathrm{t}$ & \\
\hline \multirow{4}{*}{$\begin{array}{l}\text { solvent } \\
\text { extraction }\end{array}$} & \multirow[t]{4}{*}{ Al } & \multirow{4}{*}{$\begin{array}{l}290 \text { t channel induction } \\
\text { furnaces for Al baths with } \\
\text { vibratory conveyor between, } \\
\text { described by [47]. }\end{array}$} & \multirow{4}{*}{950} & \multirow[t]{4}{*}{20} & \multirow[t]{4}{*}{0.1} & heating $20 \mathrm{~kg} \mathrm{Al}$ to $\mathrm{T}$ & $7-10 \mathrm{kWh} / \mathrm{t}$ & \multirow{4}{*}{$\begin{array}{l}\text { Al adherance, } \\
\text { oxidizes in EAF } \\
\text { (heat of forma- } \\
\text { tion: } 172 \mathrm{kWh} / \mathrm{t} \\
\text { [69]) }\end{array}$} \\
\hline & & & & & & $\begin{array}{l}\text { powering Al furnaces } \\
\text { during treatment }\end{array}$ & $20-30 \mathrm{kWh} / \mathrm{t}[95]$ & \\
\hline & & & & & & heated vibratory conveyor & $4-6 \mathrm{kWh} / \mathrm{t}$ & \\
\hline & & & & & & transition into EAF & $10-20 \mathrm{kWh} / \mathrm{t}$ & \\
\hline \multirow{4}{*}{$\begin{array}{l}\text { matte } \\
\text { extraction }\end{array}$} & \multirow[t]{4}{*}{$\mathrm{FeS}-\mathrm{Na}_{2} \mathrm{~S}$} & \multirow{4}{*}{$\begin{array}{l}\text { rotary kiln (similar to [59]) at } \\
\text { 5RPM with matte as molten } \\
\text { pool. }\end{array}$} & \multirow[t]{4}{*}{1000} & \multirow[t]{4}{*}{15} & \multirow[t]{4}{*}{0.1} & heating $10 \mathrm{~kg}$ matte to $\mathrm{T}$ & $5-6 \mathrm{kWh} / \mathrm{t}[96]$ & \multirow{4}{*}{$\begin{array}{l}\text { S contamination: } \\
\text { desulfurization } \\
\text { required, 20-30 } \\
\mathrm{kWh} / \mathrm{t}[45] .\end{array}$} \\
\hline & & & & & & $\begin{array}{l}\text { powering furnace during } \\
\text { treatment }\end{array}$ & $4-6 \mathrm{kWh} / \mathrm{t}$ & \\
\hline & & & & & & tumbling & $1-2 \mathrm{kWh} / \mathrm{t}$ & \\
\hline & & & & & & transition into EAF & $10-20 \mathrm{kWh} / \mathrm{t}$ & \\
\hline embrittlement & $\begin{array}{l}\text { oxidizing } \\
\text { atmosphere }\end{array}$ & $\begin{array}{l}\text { oxidizing tunnel furnace } \\
\text { with shaking. }\end{array}$ & 500 & 240 & $0.2-0.1$ & $\begin{array}{l}\text { powering furnace during } \\
\text { treatment }\end{array}$ & $30-45 \mathrm{kWh} / \mathrm{t}$ & Fe oxidation \\
\hline & & & & & & shaking/vibration & $1-2 \mathrm{kWh} / \mathrm{t}$ & \\
\hline & & $\begin{array}{l}\text { subsequent fluxing in rotary } \\
\text { kiln [59]. }\end{array}$ & 1000 & 15 & 0.1 & fluxing treatment & $\begin{array}{l}20-35 \mathrm{kWh} / \mathrm{t} \text { (similar } \\
\text { to matte extraction) }\end{array}$ & \\
\hline leaching & $\left(\mathrm{NH}_{4}\right)_{2} \mathrm{CO}_{3}$ & leaching reactor with stirring & 25 & 1440 & $0.2-0.1$ & aeration & $40-65 \mathrm{kWh} / \mathrm{t}$ & must be dry \\
\hline & based & and aeration [97]. & & $(24 \mathrm{hr})$ & & stirring & $30-40 \mathrm{kWh} / \mathrm{t}$ & \\
\hline & $\mathrm{NH}_{4} \mathrm{Cl}$ & heated leaching reactor with & 80 & 720 & $0.2-0.1$ & heating scrap to $\mathrm{T}$ & $15-25 \mathrm{kWh} / \mathrm{t}$ & \\
\hline & & stirring [97]. & & & & maintaining $\mathrm{T}$ & $15-25 \mathrm{kWh} / \mathrm{t}[98]$ & \\
\hline & & & & & & stirring & $15-20 \mathrm{kWh} / \mathrm{t}$ & \\
\hline & $\left(\mathrm{NH}_{4}\right)_{2} \mathrm{SO}_{4}$ & heated leaching reactor with & 80 & 1440 & $0.2-0.1$ & heating scrap to $T$ & $15-25 \mathrm{kWh} / \mathrm{t}$ & \\
\hline & based & $\begin{array}{l}\text { stirring [97] } \\
\text { followed by electrodeposition }\end{array}$ & & $(24 \mathrm{hr})$ & & maintaining $\mathrm{T}$ & $30-50 \mathrm{kWh} / \mathrm{t}$ [98] & \\
\hline & & [70] & & & & stirring & $30-40 \mathrm{kWh} / \mathrm{t}$ & \\
\hline & & & & & & electrodeposition power & 6-10 kWh/t [70] & \\
\hline $\begin{array}{l}\text { leaching with } \\
\text { prior }\end{array}$ & added to any & leaching process above & & & & heat scrap to $800^{\circ} \mathrm{C}$ & $185-280 \mathrm{kWh} / \mathrm{t}$ & \\
\hline incineration & & & & & & leaching process & $45-125 \mathrm{kWh} / \mathrm{t}$ & \\
\hline
\end{tabular}

Fig. 7-The reactor, conditions, sources of energy consumption, and secondary effects of potential solid scrap processes, grouped by type: physical (gray), high temperature (red), and leaching (green) (Color figure online).

treatments, heat is supplied by superheating in the EAF or arc heating in the ladle. The heat balance is estimated assuming the steel melt is initially at the required temperature, but that any additional reactants must be heated to temperature, and the energy of reaction and any energy losses from radiation and conduction must be included. Losses are highly dependent on the system and its geometry, so reported rates for vacuum degassing systems, ladles, and tapping are used. To overcome these losses, liquid steel has a heat capacity of $0.22 \mathrm{kWh} /$ tonne ${ }^{\circ} \mathrm{C}^{[55]}$ and an average efficiency of 50 pct for melt heating methods is reported by Breus et al. ${ }^{[56]}$ while best practice could achieve 70 pct, ${ }^{[57]}$ so a range of 50 to 70 pct is assumed here. The high-temperature solid scrap treatments could be incorporated into scrap heating. Alternative designs exist for heating scrap with waste gases and direct combustion for energy savings compared to the EAF route. ${ }^{[58,59]}$ It is assumed that heating to the process temperature in the proposed furnace is as efficient as the conventional route, and that a continuous process to the EAF could be developed, but 10 to $20 \mathrm{kWh} /$ tonne $^{[60]}$ is added to each high-temperature solid scrap process to account for heat losses during the transition to the EAF. The process heat energy would be for powering the furnace during the treatment-maintaining $1000^{\circ} \mathrm{C}$ for an additional 10 minutes, and heating the additional reactants. These requirements are informed by the breakdown of heat outputs for a steel billet reheating furnace provided by Chen et al., ${ }^{[61]}$ and an assumed heating efficiency of 40 to $60 \mathrm{pct}$. For leaching, the process takes place at room temperature, or $80{ }^{\circ} \mathrm{C}$ (in which case the energy to maintain the reactor at $80^{\circ} \mathrm{C}$ is calculated), but an additional heating step may be required before leaching. Sano et al. ${ }^{[22]}$ suggest prior incineration to remove enamel, so the specific energy consumption of raising scrap to $800{ }^{\circ} \mathrm{C}$ is added in one version of the process. Lastly, the solidification processes take place during or after casting. Unidirectional solidification would replace the standard casting process, but requires slow cooling in a high-temperature furnace. Vacuum arc re-melting is a completely auxiliary re-melting step and reported rates of energy consumption for this process in practice are used here. ${ }^{[62,63]}$ 


\begin{tabular}{|c|c|c|c|c|c|c|c|c|}
\hline \multirow{2}{*}{$\begin{array}{l}\text { process route } \\
\begin{array}{l}\text { vacuum } \\
\text { degassing } \\
\text { (minimal) }\end{array}\end{array}$} & \multirow[t]{2}{*}{ reactant } & \multirow{2}{*}{$\begin{array}{l}\text { reactor } \\
\text { tank degassing at } 100 \mathrm{~Pa}, \\
A=0.5 \mathrm{~m}^{-1}, \mathrm{k}=2 \times 10^{-5} \mathrm{~m} / \mathrm{s}[39]\end{array}$} & \multirow{2}{*}{\begin{tabular}{|l|}
$\mathbf{T}\left({ }^{\circ} \mathrm{C}\right)$ \\
1600
\end{tabular}} & \multirow{2}{*}{\begin{tabular}{|l|} 
time \\
(min)
\end{tabular}} & \multirow{2}{*}{\begin{tabular}{|l|}
$\begin{array}{l}{\left[\mathbf{C u}_{\mathbf{f}}\right]} \\
\text { (wto) }\end{array}$ \\
0.39 \\
\end{tabular}} & \multicolumn{2}{|c|}{$\begin{array}{l}\text { sources of energy consumption } \\
\text { (per tonne steel) }\end{array}$} & \multirow{4}{*}{\begin{tabular}{|l|}
$\begin{array}{l}\text { secondary } \\
\text { effects }\end{array}$ \\
other volatile \\
impurities, \\
inclusions, \\
metallic \\
elements \\
simultaneously \\
distilled
\end{tabular}} \\
\hline & & & & & & $\begin{array}{l}\text { total process energy } \\
\text { consumption }\end{array}$ & $\begin{array}{l}15 \mathrm{kWh} / \mathrm{t} \\
{[99],[45]}\end{array}$ & \\
\hline $\begin{array}{l}\text { vacuum } \\
\text { degassing } \\
\text { (vigorous) }\end{array}$ & & $\begin{array}{l}\text { re-circulation degassing at } 10 \\
\mathrm{~Pa}, \mathrm{~A}=2 \mathrm{~m}^{-1}, \mathrm{k}=6.5 \times 10^{-5} \mathrm{~m} / \mathrm{s} \\
{[39] .}\end{array}$ & 1600 & 30 & 0.32 & $\begin{array}{l}\text { total process energy } \\
\text { consumption }\end{array}$ & $\begin{array}{l}50 \mathrm{kWh} / \mathrm{t} \\
{[99],[45]}\end{array}$ & \\
\hline \multirow{3}{*}{$\begin{array}{l}\text { extended } \\
\text { vacuum } \\
\text { distillation with } \\
\text { bubbling }\end{array}$} & & \multirow{3}{*}{$\begin{array}{l}160 \text { tonne ladle with argon } \\
\text { bubbling at } 50 \mathrm{~Pa} \text {, model from } \\
{[53] \text {. }}\end{array}$} & \multirow{3}{*}{1600} & \multirow[t]{3}{*}{130} & \multirow[t]{3}{*}{0.1} & heating during treatment & $70-140 \mathrm{kWh} / \mathrm{t}[45]$ & \\
\hline & & & & & & applying vacuum & $1-2 \mathrm{kWh} / \mathrm{t}[64]$ & \multirow{4}{*}{ distilled } \\
\hline & & & & & & increased pumping & $10-20 \mathrm{kWh} / \mathrm{t}$ & \\
\hline \multirow{2}{*}{$\begin{array}{l}\text { extended spray } \\
\text { distillation in } \\
\text { vacuum }\end{array}$} & & \multirow{2}{*}{$\begin{array}{l}1 \mathrm{~mm} \text { diameter drops in } 10 \mathrm{~Pa} \\
\text { vacuum, } \mathrm{k}=6.5 \times 10^{5} \mathrm{~m} / \mathrm{s} \text { [39]. }\end{array}$} & \multirow[t]{2}{*}{1600} & \multirow[t]{2}{*}{$4 s$} & \multirow[t]{2}{*}{0.1} & heating during treatment & $125-220 \mathrm{kWh} / \mathrm{t}[98]$ & \\
\hline & & & & & & applying vacuum & $1-2 \mathrm{kWh} / \mathrm{t}[64]$ & \\
\hline \multirow{2}{*}{$\begin{array}{l}\mathrm{NH}_{3} \text { gas } \\
\text { evaporation }\end{array}$} & \multirow[t]{2}{*}{$\mathrm{NH}_{3}$ gas } & \multirow{2}{*}{$\begin{array}{l}\mathrm{NH}_{3} \text { blowing at } 200 \mathrm{~Pa} \\
\mathrm{~A}=10 \mathrm{~m}^{-1}, \mathrm{k}=3.3 \times 10^{-5} \mathrm{~m} / \mathrm{s}[40]\end{array}$} & \multirow[t]{2}{*}{1600} & \multirow[t]{2}{*}{60} & \multirow[t]{2}{*}{0.1} & heat loss during treatment & 45-115 kWh/t [45] & \multirow{2}{*}{$\begin{array}{l}\text { Nitrogen } \\
\text { supersaturation }\end{array}$} \\
\hline & & & & & & increased pumping & $10-20 \mathrm{kWh} / \mathrm{t}$ & \\
\hline \multirow{3}{*}{$\begin{array}{l}\text { sulfide } \\
\text { slagging } \\
\text { (C-sat) }\end{array}$} & \multirow[t]{3}{*}{$\mathrm{FeS}-\mathrm{Al}_{2} \mathrm{~S}_{3}$} & \multirow{3}{*}{$\begin{array}{l}160 \text { tonne ladle with } \\
\text { stirring, } A=1 \mathrm{~m}^{-1}, k=5 \times 10^{-4} \\
\mathrm{~m} / \mathrm{s} \text {. Scalable process } \\
\text { described by [54]. }\end{array}$} & \multirow[t]{3}{*}{1365} & \multirow[t]{3}{*}{50} & \multirow[t]{3}{*}{0.1} & heating $100 \mathrm{~kg}$ slag to $\mathrm{T}$ & $40-50 \mathrm{kWh} / \mathrm{t}[96]$ & \multirow{3}{*}{$\begin{array}{l}\text { prior } \\
\text { carburization, S } \\
\text { contamination: } \\
\text { desulfurization } \\
\text { required (20-30 } \\
\text { kWh/t [45]) }\end{array}$} \\
\hline & & & & & & heat loss during treatment & $\begin{array}{l}4-5 \mathrm{kWh} / \mathrm{t} \\
{[100],[101]}\end{array}$ & \\
\hline & & & & & & $\begin{array}{l}\text { stirring } \\
\text { decarburization } \\
\end{array}$ & $\begin{array}{c}1 \mathrm{kWh} / \mathrm{t} \\
+90-110 \mathrm{kWh} / \mathrm{t}[102] \\
\end{array}$ & \\
\hline $\begin{array}{l}\text { unidirectional } \\
\text { solidification } \\
\text { (C.-sat) }\end{array}$ & & $\begin{array}{l}\text { furnace at a cooling rate of } \\
60^{\circ} \mathrm{C} / \mathrm{hr} \text {. }\end{array}$ & $\begin{array}{l}1400 \text { to } \\
1000\end{array}$ & $\begin{array}{l}400 \\
(6.5 \mathrm{hr})\end{array}$ & $\begin{array}{l}\text { gradient } \\
0.4-0.32\end{array}$ & $\begin{array}{l}\text { powering furnace during } \\
\text { treatment }\end{array}$ & $\begin{array}{l}400-600 \mathrm{kWh} / \mathrm{t} \\
{[103]}\end{array}$ & \multirow{2}{*}{$\begin{array}{l}\text { other elements } \\
\text { present may also } \\
\text { form a concen- } \\
\text { tration gradient } \\
\text { and effect how } \\
\text { copper partitions }\end{array}$} \\
\hline $\begin{array}{l}\text { vacuum arc } \\
\text { re-melting }\end{array}$ & & $\begin{array}{l}\text { melting } 30 \mathrm{t} \text { ingot at } 9 \mathrm{~kg} / \mathrm{min} \\
\text { in vacuum, described by [62]. }\end{array}$ & 1600 & $\begin{array}{l}720 \\
(12 \mathrm{hr})\end{array}$ & $0.2-0.1$ & $\begin{array}{l}\text { total process energy } \\
\text { consumption }\end{array}$ & $\begin{array}{l}700-1100 \mathrm{kWh} / \mathrm{t} \\
{[62],[63]}\end{array}$ & \\
\hline $\begin{array}{l}\text { ceramic } \\
\text { filtration }\end{array}$ & $\mathrm{Al}_{2} \mathrm{O}_{3}-\mathrm{ZrO}_{2}$ & $\begin{array}{l}\text { filtration during tapping as } \\
\text { described by [45]. }\end{array}$ & 1600 & $20-30$ & 0.28 & heat loss during treatment & $20-30 \mathrm{kWh} / \mathrm{t}[45]$ & $\begin{array}{l}\text { ceramic particle } \\
\text { contamination }\end{array}$ \\
\hline
\end{tabular}

Fig. 8-The reactor, conditions, sources of energy consumption, and secondary effects of potential melt processes, grouped by type: vacuum treatments (orange), slagging (purple), and solidification segregation (blue) and ceramic filtration (brown) (Color figure online).

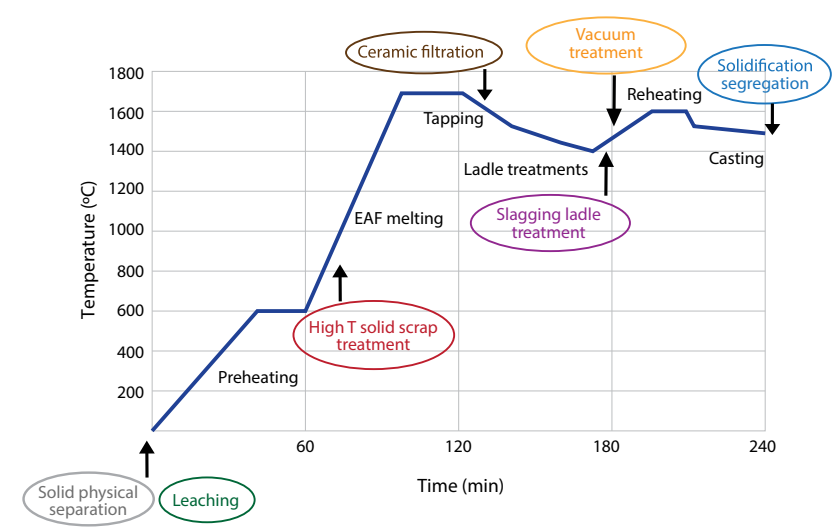

Fig. 9-Temperature-time profile of the assumed EAF route informed by Yin $^{[80]}$ with placement of potential processes.

Mechanical energy is required to improve mass transfer through shredding, tumbling, stirring, applying gas flow, or reducing chamber pressure. The rate of energy consumption for these functions is dependent on process design, so data from representative equipment are used to inform the following power requirements per tonne of steel: 0.5 to $1 \mathrm{~kW}$ for shaking/vibrating scrap, 1 to $2 \mathrm{~kW}$ steel for rotating scrap, 2 to $3 \mathrm{~kW}$ for stirring during leaching, and 1.5 to $2 \mathrm{~kW}$ for electromagnetic stirring of the melt. These requirements are then multiplied by the process time and included as a source of energy consumption, as appropriate. For reducing chamber pressure, there is a wide range of metallurgical vacuum pump systems in use. Traditional steam ejector systems require about $50 \mathrm{kWh} /$ tonne steel to achieve a vacuum, but commercially available dry pumps can reduce chamber pressure to $50 \mathrm{~Pa}$ with 1 to 2 $\mathrm{kWh} /$ tonne energy, ${ }^{[64]}$ so this figure is used here. Modern metal shredding uses approximately $20 \mathrm{kWh} /$ tonne $^{[65]}$ This figure is used to estimate the energy requirement of higher-density shredding. These sources of energy consumption for some of the processes are shown in Figures 7 and 8.

The material input required for the various processes may include a leachant, solvent, gas, or slag. These reactants are consumed and the resultant copper-containing material is a by-product, or the material may be re-circulated or re-used. To enable a fair comparison of all processes, only the amount of material directly consumed per tonne of steel processed is considered in this analysis. For leaching and solvent extraction, treatments require immersion (a typical liquid/solid ratio is $5 \mathrm{~mL} / \mathrm{g}$, e.g., 5,000 1 leachant/tonne steel, or 12 tonne liquid $\mathrm{Al}$ /tonne steel) in a leachant or solvent that can be re-used for further batches, so only the amount that must be replaced per tonne of steel treated is considered. For the leachant, the quantity of reactants consumed is calculated from the stoichiometric equation. Using aluminum as a solvent yields a valuable $\mathrm{Al}-\mathrm{Cu}$ alloy, but aluminum adheres to the scrap and is effectively oxidized in the EAF, so this lost quantity is estimated. For chloridizing and oxygen embrittlement treatments, the amount of gas consumed is calculated from the stoichiometric reaction involving copper. The amount of slag, solvent, or matte required is calculated 
from the distribution ratio at equilibrium. The associated embodied energy of these quantities of consumed material was calculated using values from the literature.

Secondary effects of the treatment, including iron oxidation, adherence of the reactant, carburization, and melt contamination have implications for energy and material consumption, and must also be considered. The chloridizing gas and oxygen embrittlement treatments also result in steel oxidation, so the iron oxidized and the oxygen consumed is estimated. The slagging ladle treatments require carbon saturation (the activity of copper is increased and the melt temperature can be reduced, which progresses the reaction of copper to copper sulfide). However, EAF's typically process low carbon steel, so the additional energy and material required for prior carburization and subsequent decarburization are also attributed to these processes. The sulfidizing matte and slag treatments contaminate the melt with sulfur, so a desulfurization ladle treatment is required. Applying an ammonia gas during copper distillation supersaturates the melt with nitrogen, so a vacuum treatment is subsequently required. These considerations are summarized in Figures 7 and 8.

\section{RESULTS}

The framework described in Section II allowed comparison of the additional energy and material required by all separation techniques for reducing copper concentration. In Figure 10, the final copper concentration achieved by each process defined in Figures 7 and 8 is plotted against the additional energy required by the process.

The processes in Figure 10 span a wide range of specific energy consumption. Processes on the far-right require long treatment times at high temperatures, while processes on the left could be incorporated nearly seamlessly into the steelmaking route. Unidirectional solidification and vacuum arc re-melting exploit the segregation of copper from steel during solidification, but this requires slow and carefully controlled cooling, and leads to limited partitioning. Vacuum arc re-melting could reliably remove copper and is in commercial operation, but because it requires re-melting in a vacuum at extremely low process rates, its use is limited to high-quality, low-volume steels for which the high energy cost is justified. On the other end of the spectrum, improved physical separation of solid scrap can be efficient and effective. Abboussouan et al. ${ }^{[66]}$ show that the copper concentration in shredded scrap varies with the size of the steel fragments, so a sieve or trommel system could isolate the copper-rich fraction. Products could be shredded to a higher density to improve liberation for magnetic separation. Preferential melting and ceramic filtration techniques appear less effective: copper adheres to scrap upon melting, and copper is absorbed from the melt onto the ceramic at a low rate.
A cluster of processes could remove copper to $0.1 \mathrm{wt}$ pct with moderate specific energy consumption (20 to $125 \mathrm{kWh} /$ tonne). The most viable appear to be the high-temperature solid scrap treatments: sulfide matte extraction, applying a chloridizing gas, and aluminum extraction, which could be incorporated into scrap heating and have fast reactions. Another viable solid scrap process is ammonium leaching, but the rate is slow and its energy consumption comes from stirring the leachant over these long treatment times. The energy cost of ammonium leaching varies widely, as the type of leachant used has implications for the process requirements (an ammonia carbonate-based leachant requires vigorous aeration, while ammonium chloride does not). Prior incineration to remove enamel and allow contact between the leachant and copper has a high energy cost. Processes requiring immersion at elevated temperature (aluminum extraction and leaching) are only viable when running continuously. To maintain the temperature of the vat, an energy requirement of 20 to 40 $\mathrm{kWh} /$ tonne steel can be expected, but the energy cost to bring the entire quantity of solvent or leachant to treatment temperature for a batch is prohibitive (over $5,000 \mathrm{kWh} /$ tonne steel for aluminum extraction at $950{ }^{\circ} \mathrm{C}$ and over $800 \mathrm{kWh} /$ tonne steel for leaching at $\left.80{ }^{\circ} \mathrm{C}\right)$.

Standard vacuum degassing has a similar energy requirement to the potential solid scrap treatments, but copper is only partially removed. Typically, melt vacuum treatments are designed to remove only gases and nonmetallic inclusions. The most vigorous degassing process in operation would reduce copper concentration to about $0.32 \mathrm{wt}$ pet. To remove more copper the reaction rate, specific surface area, or treatment time must be increased. The reaction rate, $k$, is greatest at high temperatures and low pressures (or a high scavenging gas flow rate) and with certain additions to the melt, as shown in the supplementary information. However, $k$ is limited by the rate of evaporation at the interface. The specific surface area can be increased by bubbling in a vat or spraying the melt. However, radiative heat loss is proportional to specific surface area multiplied by treatment time $\left(A^{*} \Delta t\right)$, so there is a trade-off between copper removed and the total energy required. Hidani et al. ${ }^{40]}$ applied a gas to the melt in an attempt to form a more volatile copper-containing compound, but $k$ was similar to the value in distillation and the reaction (and whether heat is added or further subtracted from the system) was not fully characterized. Overall, transferring copper from the melt to the gaseous phase is kinetically difficult.

Copper could be transferred from the melt to a liquid phase, which is kinetically easier in comparison to gaseous transfer. For sulfide slagging, $k$ is higher, the reaction is exothermic, and radiation heat losses are prevented by a thick slag during processing. However, carburization of the melt is required, which is difficult to incorporate into EAF steelmaking. Here, it is assumed that sulfide slagging would occur in a ladle process, but 


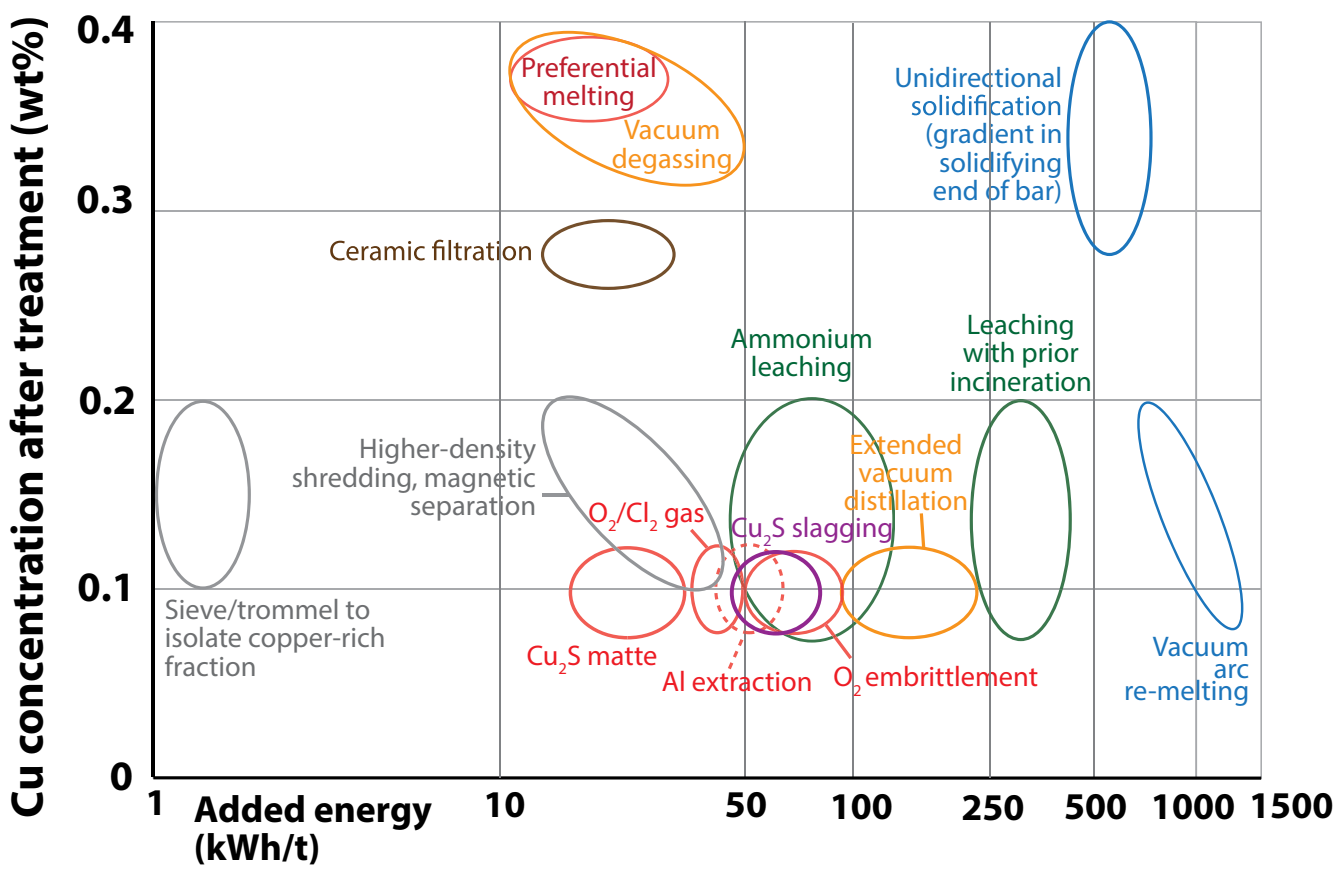

Fig. 10-The copper concentration reduction from $0.4 \mathrm{wt}$ pct and estimated specific energy consumption for the various processes defined in Figs. 7 and 8 .

commercial ladles are not equipped for carburization and decarburization. Overall, melt treatments, whether gaseous or liquid may require more energy than solid scrap treatments, but have the advantage that they can remove copper in solution, not just that external to the steel scrap.

Figure 11 shows the quantity of material required to treat one tonne of steel from 0.4 to 0.1 wt pct copper concentration in the various processes, and the associated embodied energy of the required material. Upon treatment, this material would be a by-product containing copper, but it could be re-generated or used (for example as an Al-Cu alloy in aluminum extraction). The secondary effects of the processes are shown in the right-hand side of Figure 11. Energy-based physical separations are not included as they require no direct material inputs. For the processes which require material inputs, a distinction in the amount of material required between melt and solid scrap treatments can be seen.

Melt treatments have high specific material consumption, with a minimum slag requirement of $100 \mathrm{~kg} /$ tonne. Laboratory investigations attempted to reduce this amount by optimizing slag composition. Most experiments used sodium-based additions, but Wang et al. ${ }^{[27]}$ performed a systematic survey of alkaline and alkaline earth metal sulfide additions and determined $\mathrm{Al}_{2} \mathrm{~S}_{3}$ to be the most favorable. This resulted in a distribution ratio of 30 , but this is an order of magnitude lower than the distribution ratios achieved in conventional impurity slagging, which operate with approximately $10 \mathrm{~kg}$ slag/tonne. The amount of slag required could be further reduced by iterative applications or establishing a counter-flow. Cohen et al. ${ }^{[54]}$ describe this method, as well as a process to re-generate the $\mathrm{Al}_{2} \mathrm{~S}_{3}$-based slag, but because this is operationally more difficult and would reduce the thermal efficiency of the process, it will probably not be practical for melts containing less than $1 \mathrm{wt}$ pct copper.

Sulfur contamination of the melt also renders these slags impractical. Studies report contamination of the melt with 0.1 to $1 \mathrm{wt}$ pct $\mathrm{S}$ - up to 100 times higher than levels typically encountered in refining. The sulfide-modified oxide slag designed by $\mathrm{Cohen}^{\text {[54] }}$ and the chloride slag designed by $\mathrm{Hu}$ et al. ${ }^{[67]}$ prevent sulfur contamination, but the distribution ratio of copper is much lower. Yamaguchi et al. ${ }^{[68]}$ demonstrated that metallic solvent layered between the melt and flux would prevent contamination while reducing the amount of flux required, but this is not practical because the relative densities do not allow layering in this way.

The processes applied to solid scrap generally require less material inputs than those applied to the melt, but the secondary effects of each process must be carefully considered. When applying a sulfide-based matte to solid scrap, copper is present pure, rather than dilute, so less matte is required, but sulfur contamination is still an issue - extended desulphurization, requiring an additional 20 to $30 \mathrm{kWh} /$ tonne, would be necessary. For aluminum extraction, it was estimated that $20 \mathrm{~kg} /$ tonne steel of aluminum would adhere to scrap and oxidize in the EAF. This oxidation reaction would generate up to $265 \mathrm{kWh} /$ tonne of chemical heat, ${ }^{[69]}$ but this would not be energy-efficient considering the high embodied energy of aluminum. The chloridizing gas treatment appears 


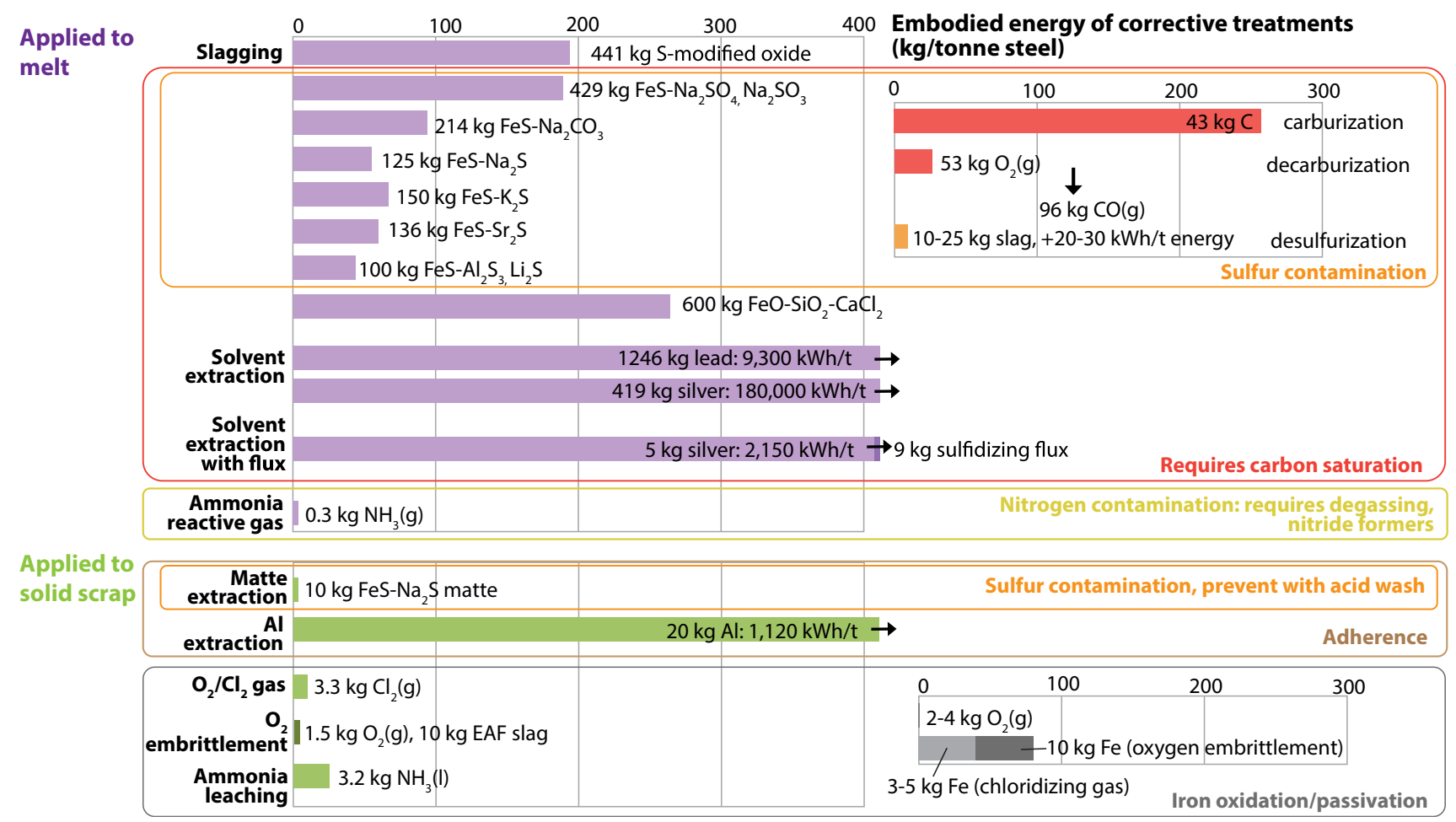

Fig. 11-Mass of material reactants (kg/tonne steel treated, labeling the bars) and the calculated associated embodied energy (kWh/tonne steel treated, plotted) to reduce copper concentration from 0.4 to $0.1 \mathrm{wt}$ pct in the various processes. Materials needed for corrective treatments, and other contamination problems caused by the treatment are shown to the right. All slag materials were calculated from the same embodied energy figure for a standard slag. The embodied energy values for metals are for the primary route.

feasible with a small amount of oxygen and chlorine consumed. Other impurities combined with steel - tin and zinc - would also chloridize, but some iron would be lost as iron oxide.

In comparing these various reactants, safety and environmental impacts must be considered. Chlorine gas is the most problematic, as it is toxic and corrosive. Alternatively, an ammonia-based leachant has a low toxicity, and Sun et al. ${ }^{[70]}$ demonstrate that copper could be deposited, while re-generating the leachant with electrowinning. Handling molten metals can be hazardous, but processes performed at high temperature could be operated at steelmaking sites, with the appropriate safety provisions and expertise.

\section{DISCUSSION}

Figure 10 shows that processes could be developed to remove copper with relatively low energy consumption. Defining a process from a principle is complex, but the thermodynamic and kinetic constraints provided in Figures 5 and 6 define the space within which a process will operate. Figure 10 shows that improved physical separation, vacuum distillation, slagging, and solid scrap pre-treatments can reduce copper concentration to $0.1 \mathrm{wt}$ pct while adding only 5 to $20 \mathrm{pct}$ to the melting energy of the EAF route. This section now considers how these four types of processes might be developed within the identified constraints to fit within steelmaking and further reduce the estimated energy and material inputs.

Physical separation in the solid state is energy-efficient, but depends on prior shredding. The cheapest light scrap is often used in EAF steelmaking because scrap accounts for approximately 70 pet of costs. ${ }^{[71]}$ Higher-density shredding may require at least twice as much specific energy as the conventional process. Whether this scrap can be directly priced according to copper content (perhaps enabled by real-time bulk composition analysis ${ }^{[13]}$, will determine the adoption of these practices by the scrap processor. A copper-rich fraction could be diverted by a trommel ${ }^{[50]}$ or ballistic system. ${ }^{[72,73]}$ In this approach, the significant fraction (20 to $30 \mathrm{pct}$ ) of diverted scrap could be directly used for products requiring copper as an alloying element (such as COR-TEN), or this step could concentrate copper before another extraction process.

High-temperature solid scrap pre-treatments also have potential for innovation. Melt processes require extended time at high temperature, but integrating a process into scrap heating might require little additional time and energy. Preferential melting appears limited by the adherence of liquid copper to steel scrap, but Leak et al. ${ }^{[7]}$ show that melting within a neutral molten salt medium, which also provides efficient heating and limits oxidation, could overcome this problem. Applying a sulfidizing matte to solid scrap appears energy-efficient, 
but the efficiency decreases when accounting for the effects of sulfur contamination. Significant progress has been made on developing an efficient leachant and process design to electrowin copper from e-waste, ${ }^{[35]}$ and these same principles could be applied to steel scrap. In general, the irregular shape of end-of-life scrap and the heterogeneous distribution of copper within it may hinder the deployment of solid scrap processes. Jimbo et al. ${ }^{[20]}$ report that 90 pet of contaminating copper is present at the surface of scrap feedstocks, but applying reactants to such a large surface area of fragmented scrap may not be practical. Additionally, copper in solution with steel from previous recycling will return in greater quantities, and these solid scrap techniques will not be effective.

The main limitation to vacuum distillation identified in this study is the radiative heat loss during an extended treatment. Previous research focused mainly on increasing the rate of copper evaporation at intermediate pressures, but low-pressure vacuums are increasingly used in metallurgy and theoretically require little energy-dry pumps significantly reduce energy and coolant water consumption compared to steam ejector systems $^{[64]}$ (although have a higher capital cost). Heat losses hinder prolonged melt vacuum treatments, but are dependent on reactor design. Therefore, opportunities exist to design optimized reactors, which shield radiation, while generating a high surface area-to-volume ratio and providing an efficient heat source. A reactive gas to evaporate a volatile copper compound may be beneficial if the reaction is exothermic and the gas does not contaminate the melt, but the gases proposed thus far are not suitable.

Removing copper through slagging is problematic. The only element that preferentially forms a compound with copper is sulfur, but this is a potent contaminant in steel. The carbon-saturation requirement and masses of slags are impractical, and given the extensive research on possible slag compositions, the space for improvement appears limited. A direction that has received little attention is applying an electric field to displace the equilibrium of copper between the melt and slag. Rose $^{[75]}$ used a cryolite-based slag containing cuprous sulfides. The current efficiency was small, but future work recommended exploring fluoride-based slags. Data on electrolytes for steel refining are lacking, as well as experimental work to support the design of a feasible cell.

This analysis focused on extraction processes, but as discussed in the introduction, there are many other supply chain interventions. Hand-picking reduces copper concentration to less than $0.25 \mathrm{wt}$ pet. ${ }^{[50]}$ The major factor limiting the efficient use of materials is the trade-off with labor, but automation could be a disruptive technology to change this dynamic. ${ }^{[76]}$ Intelligent sensing technologies, such as the system described by Shulman, ${ }^{[7]}$ were not included in this analysis, as these are sorting techniques, not separation techniques rooted in physical and chemical properties. Down-cycling contaminated scrap to tolerant applications is viable now, but interventions for copper control will be favorable when steel demand for these applications is saturated. ${ }^{[7]}$ Likewise, dilution is viable now due to abundant primary production. To dilute one tonne of steel from $0.4 \mathrm{wt}$ pct copper to $0.1 \mathrm{wt}$ pct, three tonnes of primary steel (with an average embodied energy of iron over $5,000 \mathrm{kWh} /$ tonne) is required. As the global yearly scrap supply triples from present to 2050, primary production is projected to remain constant, ${ }^{[1]}$ so this ratio for dilution will not hold.

This paper evaluated potential processes from a physical basis, rather than economic. The principles governing separation are constant and universally applicable, while prices are volatile and vary greatly region to region. Developed countries with a growing end-of-life scrap supply, dwindling ore-based production, and high-tech manufacturing industries will first confront the constraints caused by copper contamination. In these conditions, motivation to remove copper may exist, driven by the price differential between reinforcing bar and cold-rolled coil. In considering new processes, capital costs, equipment footprint, and process time are important. These considerations can be compared among the proposed processes from the information in Figures 7 and 8, as well as the descriptions of reactors in the electronic supplementary material. Capital costs may be significant, but the economics of EAF steelmaking are projected to only improve. ${ }^{[71]}$ Proper scrap management and the health of the industrial sector is in the national interest, so policies should support the transition to high-quality scrap-based production, and government-funded programs to spur innovation may considered, as discussed by Allwood. ${ }^{[78]}$

Many of the investigated processes would decrease productivity. The main focus of EAF innovations since the 1960s has been to increase productivity, because maintenance, labor, and overall plant expenditures decrease in turn. ${ }^{[71]}$ However, valuing systems and industry goals are sure to change as the urgency for reducing $\mathrm{CO}_{2}$ emissions increases. Increasing productivity does not necessarily decrease environmental impacts. For example, the more intensive use of carbon and oxygen to decrease EAF time, but directly increases $\mathrm{CO}_{2}$ emissions. The energy and material implications of processing will be a principal deciding factor in the future.

The integrated assessment provided here can be further developed as the separation routes are further characterized, or as industry advances. Estimates are based on available experimental results and the rates of energy consumption reported for current reactors, with similar industrial processes serving as benchmarks. Pilot-scale work will be required to further define the processes, and more refined models will lead to more accurate estimates. This analysis assumed that current recycling infrastructure remains unchanged with new treatments for copper separation added, but many of these treatments could be a part of larger modifications with auxiliary benefits. For example, higher-density shredded scrap improves yield in the EAF, extending vacuum treatments would refine other inclusions and metallic impurities, molten salts could provide an efficient heating and refining medium, and a treatment 
during heating could simultaneously remove other poorly controlled external impurities such as tin and zinc.

Copper in steel is just one example of a metal system constrained by contamination. Across all the main metal industries, the rate of end-of-life scrap recycling is increasing. ${ }^{[79]}$ The extent of contaminant extraction in metal recycling is determined by the historical development of the infrastructure and incentives of stakeholders along the supply chain, rather than fundamental interactions. Therefore, the possible separations for other metal systems could also be assessed with the novel framework presented in this paper.

\section{ACKNOWLEDGMENTS}

K.D. is funded by a Cambridge Trust scholarship. A.S. and J.A. are funded by EPSRC, Grant Reference $\mathrm{EP} / \mathrm{N} 02351 \mathrm{X} / 1$.

\section{OPEN ACCESS}

This article is distributed under the terms of the Creative Commons Attribution 4.0 International License (http://creativecommons.org/licenses/by/4.0/), which permits unrestricted use, distribution, and reproduction in any medium, provided you give appropriate credit to the original author(s) and the source, provide a link to the Creative Commons license, and indicate if changes were made.

\section{ELECTRONIC SUPPLEMENTARY MATERIAL}

The online version of this article (https://doi.org/10.10 07/s11663-019-01537-9) contains supplementary material, which is available to authorized users.

\section{REFERENCES}

1. S. Pauliuk, R.L. Milford, D.B. Müller, and J.M. Allwood: Environ. Sci. Technol., 2013, vol. 47, pp. 3448-54.

2. R.L. Milford, S. Pauliuk, J.M. Allwood, and D.B. Müller: Environ. Sci. Technol., 2013, vol. 47, pp. 3455-62.

3. J. Allwood: Mater. World, 2016, vol. 24, pp. 44-47.

4. K. Nakajima, O. Takeda, T. Miki, K. Matsubae, and T. Nagasaka: Environ. Sci Technol., 2011, vol. 45, pp. 4929-36.

5. O. Rod, C. Becker, and M. Nylén: Jernkontoret Report, 2006, pp. $1-59$.

6. M. Huellen, C. Schrade, U. Wilhelm, and Z. Zulhan: Ironmaking Steelmaking Conference, 2006, paper 7.1.

7. K.E. Daehn, A.C. Serrenho, and J.M. Allwood: Environ. Sci. Technol., 2017, vol. 51, pp. 6599-6606.

8. G. Leen and D. Heffernan: Computer, 2002, vol. 35, pp. 88-93.

9. K. Oba: Fujikura Tech. Rev., 2013, vol. 42, pp. 77-80.

10. Toyota, Toyota's Environmental Initiatives (Toyota, 2015): http:/ www.toyota-global.com/sustainability/report/er/pdf/er15_04_en. pdf, p. 32, Accessed January 2019.
11. T.G. Gutowski: Proceedings of IEEE International Symposium on Electronics and the Environment, 2008, pp. 1-5.

12. A. Gesing: JOM, 2004, vol. 56, pp. 18-27.

13. Gamma-Tech Analyzer: http://www.gammatech.us/Analyzer.as px. Accessed January 2019.

14. ISRI, 2018 Scrap Specifications Circular (ISRI, 2018): http://w ww.scrap2.org/specs/files/assets/common/downloads/publicatio n.pdf. Accessed January 2019.

15. Eurofer, Steel Scrap Specifications (Eurofer, 2018): www.eurofer. org/Facts\&Figures/ws.res/EurSteelScrapSpec.pdf. Accessed January 2019.

16. E. Sampson and S. Sridhar: Metall. Mater. Trans. B, 2013, vol. 44B, pp. 1124-36.

17. A. Ramadan, A. Shash, I. El-Mahallawi, D. Senk, and T. Mattar: J. Iron Steel Res. Int., 2015, vol. 22, pp. 582-89.

18. K.H. Spitzer, F. Rüppel, R. Viščorová, R. Scholz, J. Kroos, and V. Flaxa: Steel Res. Int., 2003, vol. 74, pp. 724-31.

19. L. Savov, E. Volkova, and D. Janke: RMZ Mater. Geoenviron., 2003 , vol. 50 , pp. $627-40$

20. I. Jimbo, M.S. Sulksy, and R.J. Fruehan: Iron Steelmak., 1988, vol. 15 , pp. $20-23$.

21. K. Noro, M. Takeuchi, and Y. Mizukami: ISIJ Int., 1997, vol. 37, pp. 198-206.

22. N. Sano, H. Katayama, M. Sasabe, and S. Matsuoka: Scand. J. Metall., 1998, vol. 27, pp. 24-30.

23. C. Marique: Rev. Metall. (Paris), 1996, vol. 93, pp. 1377-85.

24. Worldsteel Association, Steel Statistical Yearbooks. (Worldsteel, 2000-2018): https://www.worldsteel.org/steel-by-topic/statistics/s teel-statistical-yearbook-.html. Accessed August 2018.

25. B.K. Reck and T.E. Graedel: Science, 2012, vol. 337, pp. 690-95.

26. A.I. Zaitsev, N.Y.E. Shelkova, A.D. Livina, E.K. Shakhpazov, and B.M. Mogutnov: High Temp., 2001, vol. 39, pp. 388-94.

27. C. Wang, T. Nagasaka, M. Hino, and S. Ban-Ya: ISIJ Int., 1991, vol. 31, pp. 1300-08.

28. E.R.W. Rousseau: Handbook of Separation Process Technology, Wiley, 2009.

29. T.G. Gutowski: Materials Separation and Recycling in Thermodynamics and the Destruction of Resources, Cambridge University Press, Cambridge, 2011, pp. 113-33.

30. M.B.G. Castro, J.A.M. Remmerswall, M.A. Reuter, and U.J.M Boin: Resour. Conserv. Recycl., 2004, vol. 43, pp. 1-19.

31. K. Nakajima, O. Takeda, T. Miki, K. Matsubae, S. Nakamura, and T. Nagasaka: Environ. Sci Technol., 2010, vol. 44, pp. 55945600.

32. C.J. King: Separation Processes, McGraw-Hill, New York, 1980.

33. J.K.S. Tee and D.J. Fray: Ironmak. Steelmak., 2006, vol. 33, pp. 19-23.

34. W.D. Cho and P. Fan: US Patent 7,789,936, 2010.

35. B. Gosh, M.K. Ghosh, P. Parhi, P.S. Mukherjee, and B.K Mishra: J. Clean. Prod., 2015, vol. 94, pp. 5-19.

36. R. Suzuki and K. Ono: Proceedings of 10th International Conference on High Temperature Materials Chemistry, 2000, pp. 491-94.

37. T. Maruyama, H. Katayama, T. Momono, Y. Tayu, and T. Takenouchi: Trans. Iron Steel Inst. Jpn., 1998, vol. 84, pp. 24348.

38. L. Oden, A. Fugate, and A. Adams: U.S. Bureau of Mines, Report 7776, 1973

39. L. Savov and D. Janke: ISIJ Int., 2000, vol. 40, pp. 95-104.

40. T. Hidani, K. Takemura, R.O. Suzuki, and K. Ono: Trans. Iron Steel Inst. Jpn., 1996, vol. 82, pp. 135-40.

41. M. Sasabe, E. Harada, and S. Yamashita: Trans. Iron Steel Inst. Jpn., 1996, vol. 82, pp. 129-34.

42. H. Konishi, T. Bitoh, H. Ono, T. Oishi, K. Koyama, and M. Tanaka: J. JSEM, 2014, vol. 14, pp. 205-09.

43. R.J. Andreini and J.S. Foster: J. Vac. Sci. Technol., 1974, vol. 11, pp. $1055-59$

44. T.A. Engh: Principles of Metal Refining, Oxford University Press, Oxford, 1992.

45. A. Ghosh: Secondary Steelmaking: Principles and Applications, CRC Press, Boca Raton, 2000.

46. M. Nakamoto, Y. Okumura, T. Tanaka, and T. Yamamoto: Trans. Iron Steel Inst. Jpn., 2014, vol. 100, pp. 761-68.

47. M. Iwase: Steelmaking Conference Proceedings, 1996, pp. 633-40. 
48. R.J. Fruehan and A.W. Cramb: Final Report to Department of Energy, 1991.

49. R.R. Brown, and F.E. Block: U.S. Bureau of Mines, Report 7218, 1968.

50. S. Newell: UK Electric Steelmakers Conference, May 2017.

51. R. Harris: Can. Metall. Q., 1988, vol. 27, pp. 169-78.

52. N.A. Warner: Metall. Mater. Trans. B, 2004, vol. 35B, pp. 663-74.

53. A.I. Zaitsev, N.E. Zaitseva, E.K. Shakhpazov, and B. Mogutnov: ISIJ Int., 2004, vol. 44, pp. 639-46.

54. A. Cohen and M. Blander: Metall. Mater. Trans. B, 1998, vol. 29B, pp. 493-95.

55. G.J.W. Kor and P.C. Glaws: Ladle Refining and Vacuum Degassing, in Steelmaking and Refining, The AISE Steel Foundation, Pittsburgh, 1998.

56. V.M. Breus, Y.L. Kats, and A.A. Klachkov: Metallurgist, 1999, vol. 43 , pp. $38-41$.

57. P. Goodman, C. Robertson, A. Skarstein, L. Lyonas, S. Pahal: ERA Technology, Report No. 2012-0230, 2012.

58. T. Jiemin, W. Xuefeng, M.B. Ferri, and P. Argenta: Steel Times Int., 2005, vol. 29, p. 34.

59. Y. Zhang, P.V. Barr, and T.R. Meadowcroft: Miner. Eng., 2008, vol. 21, pp. 178-89.

60. Entec: Iron and Steel-Electric Arc Furnace steelmaking, April 2006

61. W. Chen, Y. Chung, and J. Liu: Int. Commun. Heat Mass Transf., 2005, vol. 32, pp. 695-706.

62. H. Scholz, U. Biebricher, H. Franz, A. Paderni, and P. Bettoni: State of the Art in VAR and ESR Processes-A Comparison (ASO Group Steel, 2014), http://www.asogroupsteel.com/wp-co ntent/uploads/2014/05/var-and-esr-processes.pdf. Accessed September 2018.

63. J. Krüger, M. Reuter, C. Kögler, and T. Probst: Metallurgical Furnaces, Wiley, Weinheim, 2005.

64. V.A. Kuznetsov and Y.L. Kats: Metallurgist, 2007, vol. 51, pp. 220-25.

65. H. Lassesson: Masters Thesis, Chalmers University of Technology, 2008.

66. L. Aboussouan, P. Russo, M.N. Pons, D. Thomas, J.P. Birat, and D. Leclerc: Powder Technol., 1999, vol. 105, pp. 288-94.

67. X. Hu, Z. Yan, P. Jiang, L. Zhu, K. Chou, H. Matsuura, and F, Tsukihashi: ISIJ Int., 2013, vol. 53, pp. 920-22.

68. K. Yamaguchi, H. Ono, and T. Usui: Trans. Iron Steel Inst. Jpn., 2010 , vol. 96 , pp. $531-35$.

69. Z. Adolf and L. Socha: Secondary Metallurgy (Ostrava, 2016), http://katedry.fmmi.vsb.cz/Opory_FMMI_ENG/2_rocnik/MM T/Secondary\%20Metallurgy.pdf. Accessed September 2018.

70. Y. Sun, Y. Xiao, J. Sietsma, H. Agterhuis, and Y. Yang: Environ. Sci. Technol., 2015, vol. 49, pp. 7981-88.

71. Y.N. Toulouevski and I.Y. Zinurov: Innovation in Electric Arc Furnaces, Springer, New York, 2010.

72. Steinert SteelMaster (Steinert, 2018): https://steinertglobal.com/ us/magnets-sensor-sorting-units/magnetic-separation/magnetichead-pulleys/steinert-steelmaster/. Accessed January 2019.

73. M. Shattuck and C. Ramsdell: The case for producing low-copper steel with ballistic separators (Waste Advantage, 2018), https://wasteadvantagemag.com/the-case-for-producing-low-cop per-steel-with-ballistic-separators/. Accessed January 2019.

74. V.G. Leak and M. Fine: U.S. Patent 3,776,718, 1973.

75. A.J. Rose: Ph.D. Dissertation, University of Cambridge, 1981.
76. The Circular Economy-A Powerful Force for Climate Mitigation (Material Economics, 2018): http://materialeconomics.com/ publications/publication/the-circular-economy-a-powerful-for ce-for-climate-mitigation. Accessed January 2019.

77. A.D. Shulman: U.S. Patent No. 7,886,915, 2011.

78. J. Allwood: A Bright Future for UK Steel, University of Cambridge, Cambridge, 2016.

79. T.G. Gutowski, S. Sahni, J.M. Allwood, M.F. Ashby, and E. Worrell: Philos. Trans. R. Soc. A, 2013, vol. 371, p. 20120003.

80. R. Yin: Metallurgical Process Engineering, Metallurgical Industry Press, Beijing, 2009.

81. S. Zhou, S. Shen, D. Zhao, Z. Zhang, and S. Yan: J. Therm. Anal. Calorim., 2017, vol. 129, pp. 1445-52.

82. E.A. Brandes and G.B. Brook: Smithells Metals Reference Book, 7th ed., Butterworth-Heinemann, Oxford, 1992.

83. C.H.P Lupis: Chemical Thermodynamics of Materials, North-Holland, New York, 1983.

84. T.P. Hoar and G.P. Rothwell: Electrochim. Acta, 1970, vol. 15, pp. 1037-45.

85. D.L. Perry: Handbook of Inorganic Compounds, 2nd ed., CRC Press, 2016

86. K. Yamaguchi, H. Ono, and T. Usui: Mater. Trans., 2010, vol. 51 , pp. $1222-26$.

87. D.R. Lide: CRC Handbook of Chemistry and Physics, 87th ed., CRC Press, Boca Raton, FL, 2006.

88. L.L. Oden, G.W. Elger: U.S. Bureau of Mines, 1987, Report 9139.

89. M. Van Ende and I. Jung: Metall. Mater. Trans. B, 2017, vol. 48B, pp. 28-36.

90. K. Yamaguchi and Y. Takeda: Mater. Trans., 2003, vol. 44, pp. $2452-55$.

91. K. Yamaguchi and H. Ono: ISIJ Int., 2012, vol. 52, pp. 18-25.

92. K. Yamaguchi, H. Ono, and E. Takeuchi: Trans. Iron Steel Inst. Jpn., 2015, vol. 101, pp. 636-44.

93. A. Cohen: Ph.D. Dissertation, Northwestern University, 2005.

94. Trommels (Bianna Recycling, 2018): http://biannarecycling.co $\mathrm{m} / \mathrm{en} /$ trommel/. Accessed January 2019.

95. W. Schmitz and D. Trauzeddel, The Melting, Holding and Pouring Process-Energy and Process-Related Aspects (Otto Junker, 2014), http://www.hossl.com/archivos/201605/articulo-j unker.pdf?1. Accessed September 2018.

96. J.W. Matousek: JOM, 2008, vol. 60, pp. 62-64.

97. J. Jung and W. Keller: Erzmetall, 2016, vol. 69, pp. 108-118.

98. Energy Consumption of Tanks and Vats (Spirax Sarco Limited, 2018): http://www.spiraxsarco.com/Resources/Pages/Steam-Engi neering-Tutorials/steam-engineering-principles-and-heat-transfer /energy-consumption-of-tanks-and-vats.aspx. Accessed September 2018 .

99. O. Winkler and R. Bakish: Vacuum Metallurgy, Elsevier, New York, 1971.

100. K.W. Lange: Int. Mater. Rev., 1988, vol. 33, pp. 53-89.

101. J. Alexis, P. Jönsson, and L. Jonsson: ISIJ Int., 2000, vol. 40, pp. 1098-104.

102. J. Madias: Treatise on Process Metallurgy, vol. 3, Elsevier, 2014.

103. N. Margolis and R. Brindle: U.S. Department of Energy Office of Industrial Technologies, 2000.

Publisher's Note Springer Nature remains neutral with regard to jurisdictional claims in published maps and institutional affiliations. 